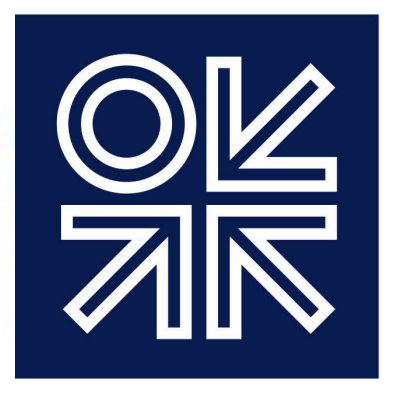

THE OXFORD

INSTITUTE

FOR ENERGY

STUDIES

JULY 2014

\title{
US climate change policy and the power sector
}

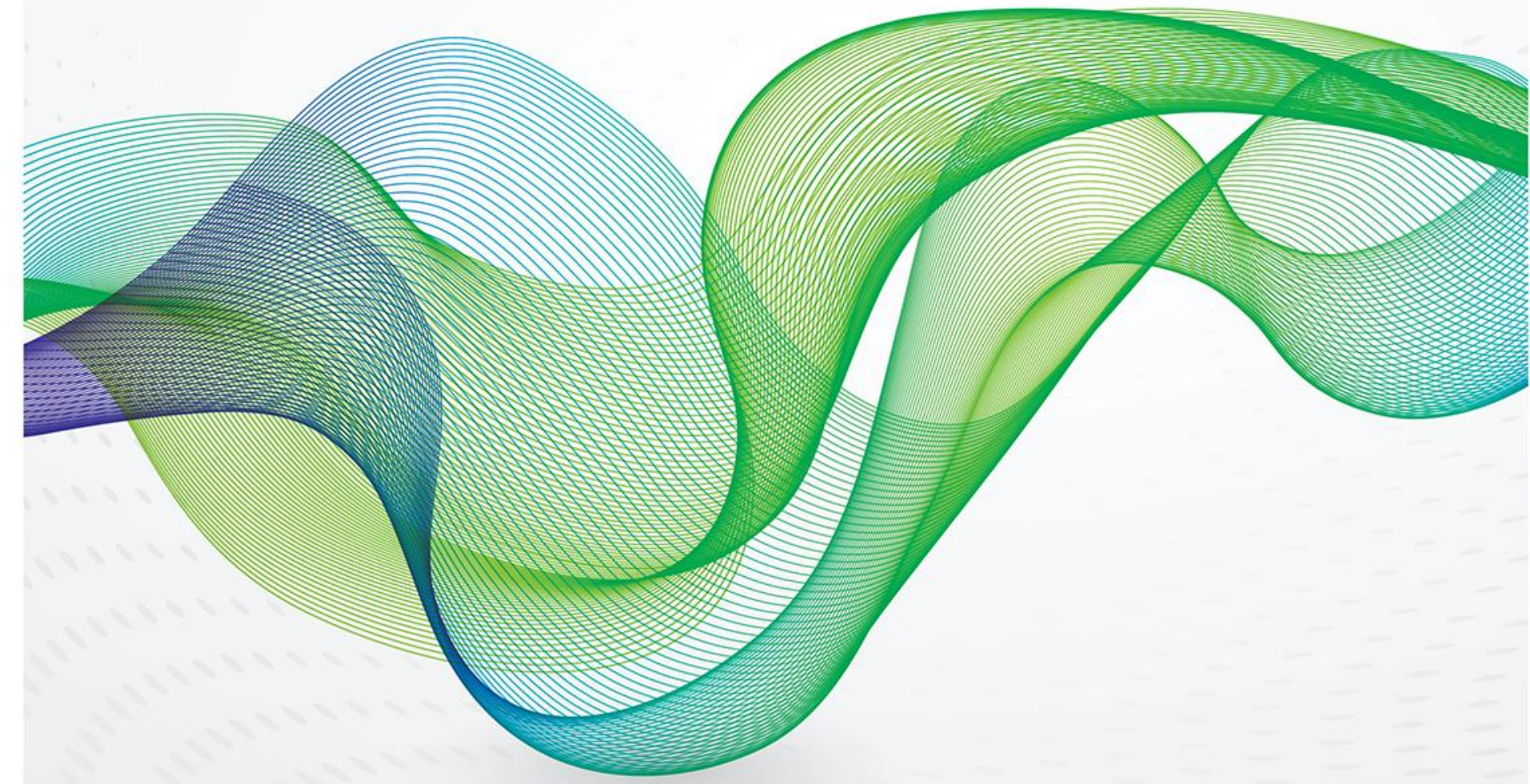

David Robinson* 
The contents of this paper are the author's sole responsibility. They do not necessarily represent the views of the Oxford Institute for Energy Studies or any of its Members

\author{
Copyright @ 2014 \\ Oxford Institute for Energy Studies
}

(Registered Charity, No. 286084)

This publication may be reproduced in part for educational or non-profit purposes without special permission from the copyright holder, provided acknowledgment of the source is made. No use of this publication may be made for resale or for any other commercial purpose whatsoever without prior permission in writing from the Oxford Institute for Energy Studies.

ISBN 978-1-78467-006-1 


\section{Contents}

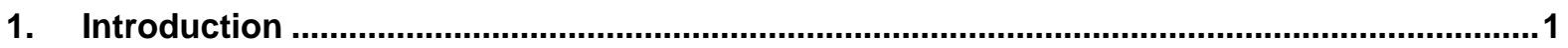

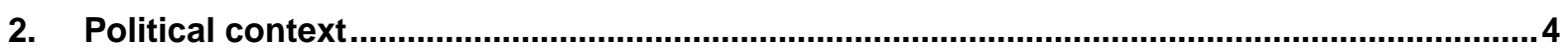

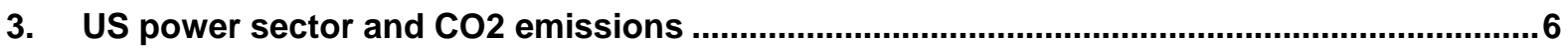

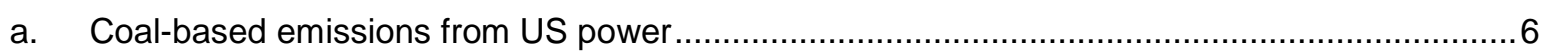

b. $\quad$ The challenge of lowering emissions at coal plants in the US .................................................. 7

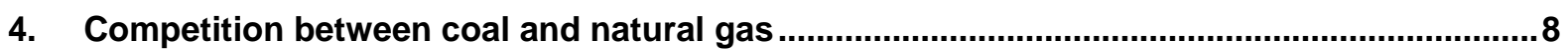

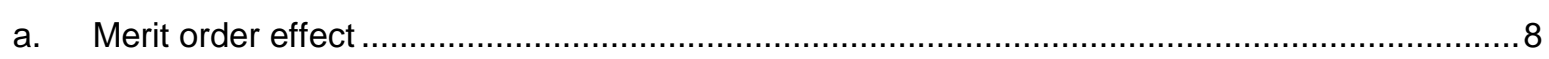

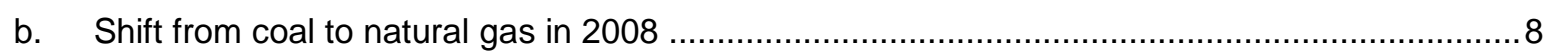

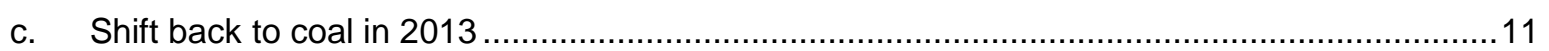

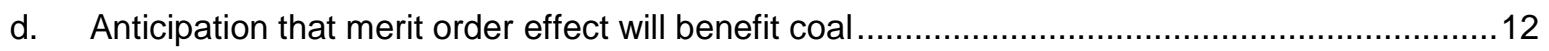

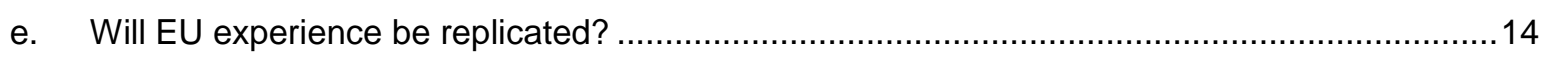

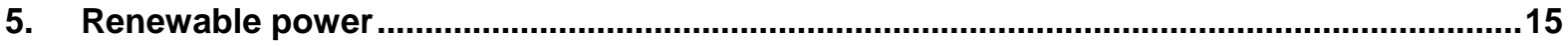

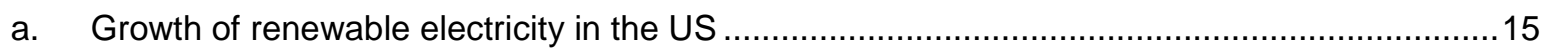

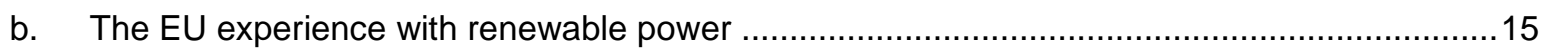

6. Electricity demand growth (and distributed generation) .................................................16

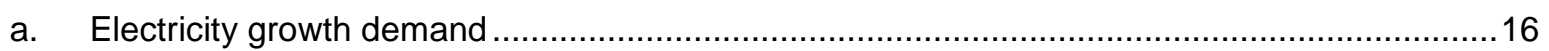

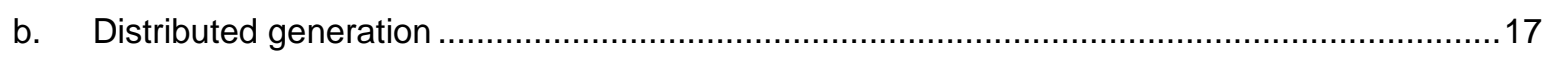

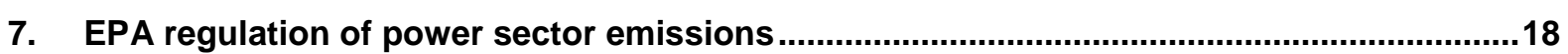

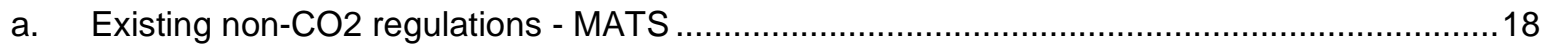

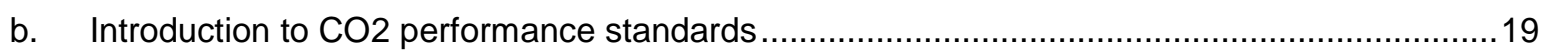

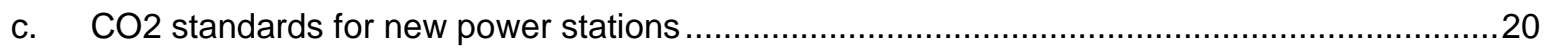

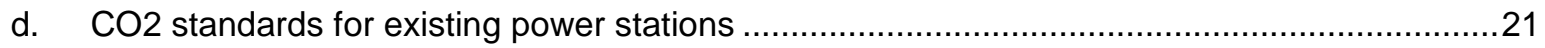

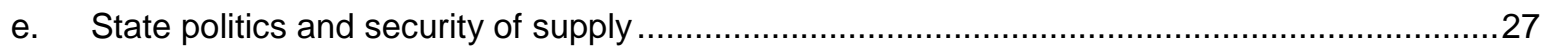

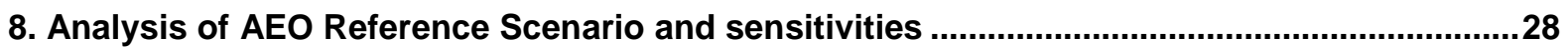

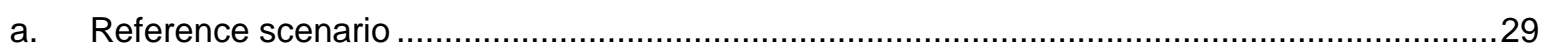

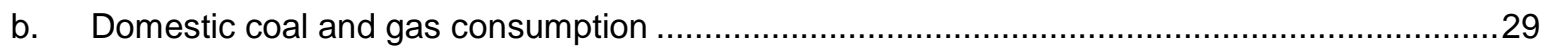

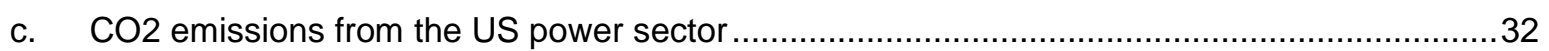

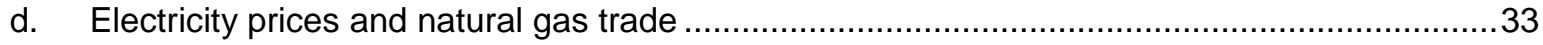

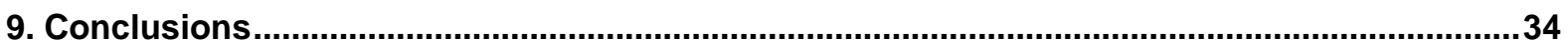




\section{Graphics}

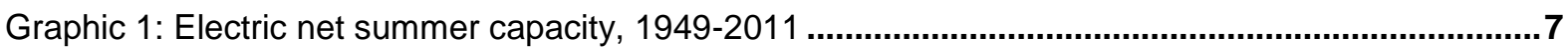

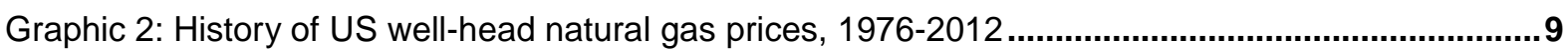

Graphic 3: EIA AEO 2013: relative price of natural gas to coal in US ........................................13

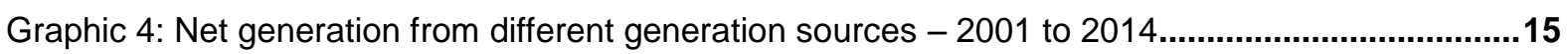

Graphic 5: US retail sales of electricity, 2001-2013 ..............................................................17

Graphic 6: Installed buildings, distributed generation capacity (GW) ..............................................18

Graphic 7: EPA forecasts for coal production if proposals on $\mathrm{CO} 2$ emissions are adopted ................25

Graphic 8: EPA estimates of US generation mix with EPA proposed performance standard (GWh) ..26

Graphic 9: EPA estimate for power sector gas use with EPA proposed performance standard ...........26

Graphic 10: Coal consumption in the US power sector, 2010-2040 (million short tons) ......................31

Graphic 11: Natural gas consumption in the US power sector (Tcf), 2010-2040 ................................32

Graphic 12: Energy related CO2 emissions from the US power sector ...........................................33

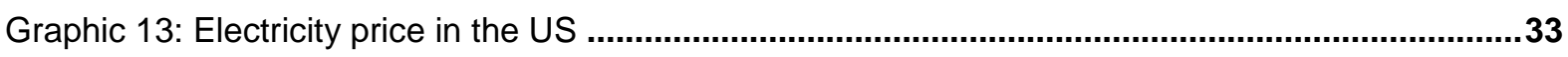

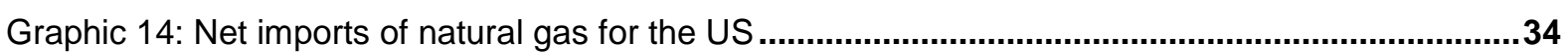

\section{Tables}

Table 1: World energy related CO2 emissions (Mt), 1990-2035 in IEA New Policies Scenario.............6

Table 2: Average cost of fuels for US electric power industry 2002-2012 (\$MMBTU) ........................10

Table 3: Consumption of coal and natural gas in the US power sector, 2002-2012 ............................10

Table 4: Electricity supply by fuel in 2011-2013 (billion kWh).......................................................11

Table 5: Cost of fuels for electric power industry, January 2014 and January 2013 (\$/physical unit)..12

Table 6: US Net generation and consumption of fuels for January 2013 and January 2014 .... .12 


\section{Introduction}

On 2 June 2014 the US Environmental Protection Agency (EPA) published its proposed performance standards to reduce $\mathrm{CO} 2$ emissions from existing power stations. In 2012, these stations accounted for about $38.5 \%$ of US energy-related CO2 emissions, chiefly from coal. To date, the EPA proposal is the most substantial federal policy initiative aimed at reducing $\mathrm{CO} 2$ emissions in the US. However, other developments will also influence $\mathrm{CO} 2$ emissions from the power sector.

In this paper, I place the proposed EPA regulations into their wider political and sectorial context. I then analyze four determinants of the demand for coal and gas in the power sector, and of the resulting $\mathrm{CO} 2$ emissions: the relative price of coal and natural gas; electricity demand; renewable power; and EPA regulations.

There are four messages. First, reductions in $\mathrm{CO} 2$ emissions from the US power sector are likely to be modest, at least from a European perspective. Coal and natural gas will together continue to provide over 60 per cent of US electricity until at least 2030. Second, achieving EPA objectives for $\mathrm{CO} 2$ emissions reduction will be difficult, which partly explains why the targets are modest. There are barriers to reducing coal-based generation in the US, including the relatively low cost of coal and strong political support for coal in many states. Third, while the market share for natural gas will grow, its market in the power sector will be limited by rising natural gas prices, growth of renewables and flat or declining electricity demand. Finally, absence of bipartisan support for federal action to tackle climate change raises doubts about the successful implementation of EPA regulations and weakens US credibility in global climate negotiations.

This paper is divided into the following sections. Section 2 examines the fundamental political problem facing efforts to address climate change in the US: the absence of bipartisan and public support for action. This largely explains the inability to pass comprehensive federal climate change legislation and the president's decision to use executive actions to instruct the EPA to regulate CO2 emissions in the power sector. From an economic perspective, sector-specific regulation is not optimal; it would be more efficient (greater net benefits versus costs) to introduce a federal cap-and-trade mechanism or a carbon tax. From a domestic political perspective, EPA regulations elicit strong opposition from individual states and affected parties. Internationally, the absence of support for federal legislation and regulation weakens the credibility of the US in climate change negotiations.

Section 3 introduces the challenges related to coal-based generation in the US, where these plants are old and inefficient by comparison to the best in the world. It emphasizes the large contribution of coal-based generation to US $\mathrm{CO} 2$ emissions, and identifies four critical determinants of the future demand for coal and gas, and of $\mathrm{CO} 2$ emissions in the power sector: competition between coal and gas; the growth of renewable generation; lower demand for fossil fuel based electricity as a result of improved energy efficiency; and regulation of emissions. $\mathrm{CO} 2$ emissions in the US have already fallen since 2008 , largely as a result of these four factors.

Section 4 analyzes competition between natural gas and coal in the power sector. The discovery and production of shale gas, and the related decline in the price of natural gas since 2008, led to substitution of coal by natural gas in the power sector merit order. This substitution was made possible due to the existence of excess capacity of gas-fired power plants built in the 1990s and early 2000s. However, since 2012 coal has regained market share from natural gas, which has been rising in price relative to coal, and government price forecasts suggest that coal will be increasingly competitive against gas in the future. The major questions are to what extent this price differential will favor coal, and whether the US will follow the EU example - where the combination of low CO2 prices 
and low coal prices lowered the expected demand for gas-fired generation. It is not unrealistic to imagine a similar scenario in the US.

Section 5 notes that renewable energy has already grown substantially and is expected to continue to grow in absolute terms and as a share of total generation. Though this lowers $\mathrm{CO} 2$ emissions and demand for both coal and natural gas, the full impact on these fuels will depend on what role they play in an increasingly decarbonized system: providing backup for renewables, base-load power or both. This will depend on the penetration of renewables, and on the relative prices of coal, natural gas and $\mathrm{CO} 2$ emissions. In Europe, low prices for coal and $\mathrm{CO} 2$ emission allowances, along with high gas prices have enabled coal to gain market share at the expense of gas. This might happen in the US if gas prices rose substantially in relative terms.

Section 6 stresses the importance of electricity demand for coal- and gas-based generation. US electricity demand is below the level reached in 2007 and growth prospects are uncertain, with EPA proposals, for instance, implying a decline in electricity demand by 2030. Furthermore, the growth of distributed generation - especially rooftop solar photovoltaics (PV) - lowers the residual demand for electricity produced by coal and natural gas. Slow or negative final demand and greater distributed generation (from renewables) would lower $\mathrm{CO} 2$ emissions, along with the expected demand for both coal and natural gas.

Section 7 firstly explains that coal-based generation must already comply with existing EPA performance standards for many different emissions, including mercury and other toxic substances. The related compliance costs are accelerating early closure of coal power stations, with estimates of closures ranging between 10-25 per cent of the existing fleet of coal plants ( $310 \mathrm{GW}$ ).

Secondly, it looks at the EPA's CO2 performance standards for new power plants, and the recently published proposed standards for existing power plants - especially coal-based generation. In the short to medium term, the standards for new plants are not as important as the proposals for existing plants, because few new plants are needed in the US. The EPA proposals for existing power plants aim to reduce power sector emissions by 30 per cent in 2030 compared to 2005 . These regulations target coal-fired electricity, while favoring natural gas, nuclear and renewables.

Broadly speaking, there are two different interpretations of how the EPA's proposed performance standards for existing stations will fare. One is that most or all of the states will collaborate with the EPA to introduce mechanisms to achieve the $\mathrm{CO} 2$ reductions required by the agency's performance standards. The EPA has written its proposals in a way that gives the states flexibility in the mechanisms they choose to achieve the standards, including plant-specific measures as well as emissions trading schemes, greater output from lower-carbon technologies, and improved energy efficiency on the demand side. Nevertheless, these performance standards are complex and impose compliance costs unevenly among states. They also require difficult decisions about burden sharing within states.

The other interpretation, which I consider to be more realistic, is that opposition to these standards will lead to political efforts to weaken the regulation, with the possibility that a change in the Senate majority or in the party holding power after the next presidential elections could slow or even lead to abandonment of the EPA process. Legal precedent supports the EPA's authority to regulate CO2 emissions, but that will not stop litigation and political opposition from slowing the process. Even in the more optimistic scenario, the resulting reduction in emissions will be only 18 per cent in 2030, compared to 2012 levels, because emissions have already fallen 12 per cent since 2005. By European standards, this is a modest target. 

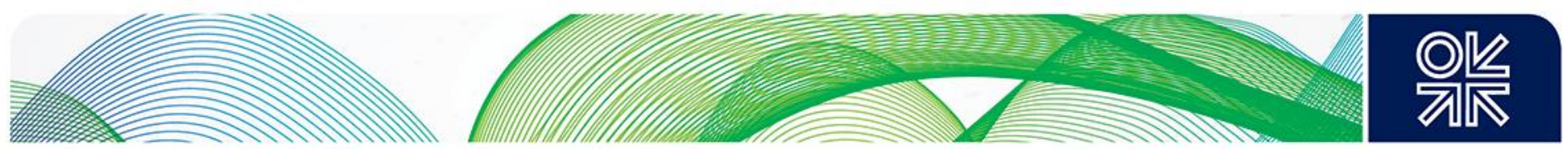

Thirdly, this section illustrates how state politics will influence the wider debate about EPA regulations that affect coal. The issue of electricity reliability is likely to be a particular source of concern in areas where closure of power stations could increase vulnerability to brown-outs or black-outs. Furthermore, with mid-term elections in November, allegations of a White House 'war on coal' will hurt Democrat candidates in states that produce or consume significant quantities of coal.

Section 8 illustrates how the issues analyzed above (gas-coal price differentials, electricity demand growth, growth of renewables and the regulation of $\mathrm{CO} 2$ emissions) could influence coal and natural gas consumption in the US power sector, $\mathrm{CO} 2$ emissions, electricity prices and natural gas trade. It compares the EIA 2014 Reference Case Scenario against sensitivities related to the four issues. Of all these factors, putting a price on $\mathrm{CO} 2$ emissions has the largest impact on future demand for coal and on $\mathrm{CO} 2$ emissions, but that impact depends on the price of $\mathrm{CO} 2$ and on the relative prices of natural gas and coal. It also illustrates how slower growth in electricity demand and lower costs for renewable power generation would reduce coal and natural gas sales, and also lower CO2 emissions below the EIA's Reference Scenario.

The paper concludes that fossil fuels will continue to dominate the US power sector for the next 20 years or more, and that even if the EPA's proposed regulations are successfully introduced, coal and natural gas will generate over 60 per cent of electricity in 2030. Consequently, the EPA's regulations for existing plants imply a modest 18 per cent reduction in power sector emissions in 2030 compared to 2012. Furthermore, controversy and litigation over EPA regulations, and/or a rising price differential between natural gas and coal, could slow the process of reducing coal-based generation and $\mathrm{CO} 2$ emissions. Although natural gas gains power market share in most scenarios, renewables, slow electricity demand growth, and high gas prices would all slow the growth of natural gas sales. Finally, the absence of bipartisan consensus and public support weakens US credibility in global (UNFCCC) climate change negotiations. However difficult it seems, the challenge is to forge bipartisan consensus on the need to address climate change ${ }^{1}$.

This paper draws mainly on data from two public sources, in addition to the EPA's proposed regulations of power stations: the International Energy Agency, in its World Energy Outlook 2013 (IEA WEO 2013) for world CO2 emissions; and the US Department of Energy's Energy Information Administration (EIA), for the electricity sector, coal and gas markets, and CO2 emissions in the US. The EIA provides historic time series data for US energy developments and provides forecasts based on current policies. The EIA also has an interactive model of their Annual Energy Outlook 2014 (AEO 2014), and I use that model mainly in Section 8 to quantify the impact of different sensitivities studied in this paper.

\footnotetext{
'I welcome the bipartisan initiative, called the 'Risky Business Project', which aims - according to the Financial Times article to change the way that business thinks about climate change in the US. It is backed by former Treasury Secretaries Hank Paulson, Robert Rubin and George Shultz, and is chaired by Mr Paulson, Michael Bloomberg and Tom Steyer. (Financial Times, 19 June 2014, p.3)
} 


\section{Political context}

In November 2008 expectations were high that federal climate change legislation would be enacted ${ }^{2}$. The Democratic Party controlled both Houses of Congress, and the newly elected President, Barack Obama, was clearly a supporter of such legislation. The American Clean Energy and Security Act (ACES) would have adopted an emissions trading plan similar to the EU's Emission Trading Scheme. It offered transitional support to the coal sector and its customers, and looked likely to become federal legislation ${ }^{3}$. Although it was approved by a small margin in the House of Representatives in June 2009, ACES was not approved in the Senate 4 .

The failure of the administration to pass the bill reflects a regional split within the Democratic Party, and the fact that climate change has become a partisan issue. ACES differed from previous attempts to pass climate change legislation, which had been sponsored by leaders from different parties, notably John McCain and Joe Lieberman. ACES was sponsored by two 'coastal Democrats', Congressman Henry Waxman of California and Congressman Edward Markey of Massachusetts. The industrial and coal-dependent Midwest was represented by a number of Democratic senators and congressmen. In the House of Representatives, 44 Democrats, mostly from Republican-leaning or coal mining districts in the Midwest and South voted against the bill. In the Senate, Democrats who were reluctant to support ACES came to be known as the 'Gang of 16'. Without their support the Democratic Party could not gain the 60-vote super-majority needed to pass the legislation in the Senate, and indeed would not have been able to achieve a majority of 50 votes.

Since 2009, it has been apparent that there is no bipartisan support for climate change legislation ${ }^{5}$. The political reality is that the climate change issue has become an almost ideological battleground, where science seems not to matter. In 2009, a Pew poll found that 67 per cent of Republicans thought the climate was warming due to natural causes or was not warming, versus 64 per cent of Democrats who thought that the earth was warming mainly due to human activity ${ }^{6}$. A more recent Gallup poll from March 2014 - indicated that 51 per cent of respondents think environmental protection should take precedence over energy production; 70 per cent of Democrats agreed with this, compared to 30 per cent of Republicans7. The Gallup poll also indicated that 36 per cent of Democrats see climate change as a policy priority, compared to 10 per cent for Republicans, and that 45 per cent of Democrats see the environment as a major concern, compared to only 16 per cent for Republicans ${ }^{8}$.

\footnotetext{
2I have benefited from reading a draft of a chapter in a forthcoming book: Ellerman, Denny, "The Shifting Locus of Global Climate Policy Leadership" in Bakker, Christine and Francesco Francioni (eds.), The EU, the US and Global Climate Governance, Ashgate Publishing (forthcoming in 2014), pp. 41-57.

S See the paper I wrote on the potential deal that was on the table in 2009. "US Energy and Climate Change: The Big Deal", EV47 October 2009. http://www.oxfordenergy.org/wpcms/wp-content/uploads/2011/03/EV47USEnergyandClimateLegislationThe-Big-Deal-DRobinoson-2009.pdf

${ }^{4}$ ACES never went to a vote in the Senate. Time ran out on it and the bill was not re-introduced in the next Congress.

${ }^{5}$ For some history on the move by Republicans away from market-based options, see Robert Stavins "EPA's Proposed Greenhouse Gas Regulation: Why Are Conservatives Attacking its Market Based Options?", June 52014. http://www.robertstavinsblog.org/2014/06/05/epas-proposed-greenhouse-gas-regulation-why-are-conservatives-attacking-itsmarket-based-options/

${ }^{6}$ http://www.people-press.org/2009/07/09/section-5-evolution-climate-change-and-other-issues/ (last consulted, 22 June 2014). 7 http://www.gallup.com/poll/170885/smaller-majorities-favor-gov-pollution-controls.aspx (last consulted, 21 June 2014).

${ }^{3}$ http://www.gallup.com/poll/167843/climate-change-not-top-worry.aspx (last consulted, 22 June 2014).
} 
Within the lobbying community there is also a pretty clear divide between the environmental groups, which tend to support the Democrats, and the fossil fuel lobbies, which usually support the Republicans. There are of course variations within each of these two categories; for instance some Republican leaders are more concerned about environmental protection and some Democrats are more concerned about supporting fossil fuel development. There are also nuances within each lobby group; for instance the gas lobby argues that it is 'cleaner' than coal, and there are differences among environmental lobbies about whether to support natural gas even though it is a fossil fuel. Nevertheless, I do not believe there is much debate about the general political allegiance of the two interest groups.

In the absence of the required cross-party support to pass federal climate change legislation, the President decided that he would rely on executive actions. In his 2013 State of the Union Address, he said:

'I urge this Congress to pursue a bipartisan, market-based solution to climate change, like the one John McCain and Joe Lieberman worked on together a few years ago. But if Congress won't act soon to protect future generations, I will. I will direct my Cabinet to come up with executive actions we can take, now and in the future, to reduce pollution, prepare our communities for the consequences of climate change, and speed the transition to more sustainable sources of energy ${ }^{9}$ '.

The most potent example of this was the president's Climate Action Plan (CAP), presented in June 2013, along with instructions to the EPA to introduce CO2 emissions standards for coal-fired power stations.

The president's strategy is clearly second best. President Obama had publicly committed himself to taking action to address climate change and is personally convinced of the importance of doing so. By using executive actions, he faces stiff resistance from the negatively affected parties, as well as the prospect of protracted litigation and heavy political penalties (for instance in the upcoming mid-term elections). Furthermore, economists generally agree that sector-specific regulation of $\mathrm{CO} 2$ is less efficient than the introduction of a single price for carbon emissions, whether through a carbon tax or a cap-and-trade emissions trading system, and that the inefficiencies are even greater when regulatory mechanisms vary widely from state to state ${ }^{10}$.

Are executive actions the 'only game in town? Probably, yes; in which case, perhaps we should be pleased that a step is being taken in the right direction. However, it is worrying that decisions of this importance do not command more public support, and that future administrations might - in a tit for tat move - water down the EPA's proposed rules or derail the process altogether. When the going gets really tough and both sides get tired of litigation, one possible way forward would be to return to the proposal for federal legislation; for instance a revenue-neutral carbon tax that has been mooted by both Democrats and Republicans.

As long as political consensus for action remains absent, the US will be less credible in international negotiations. Evidence of executive actions will give the US something to show in the upcoming discussions related to reaching a global climate change deal in Paris in 2015. However, other countries are bound to wonder whether the US will be able to deliver on its domestic objectives, quite apart from any international commitments it might make.

\footnotetext{
${ }^{9}$ President Barack Obama's State of the Union Address - As Prepared for Delivery, 12 February 2013.

${ }^{10}$ See for instance, J.E. Aldy, "The Case for a US Carbon Tax", Oxford Energy Forum no. 91, 2013.
} 


\section{US power sector and $\mathrm{CO} 2$ emissions}

It is not surprising that the President's main executive actions focus on the power sector. For people concerned about climate change, reducing global emissions from the power sector is critical. In absolute terms, global coal-based generation is increasing fast and is now the most important single source of $\mathrm{CO} 2$ emissions. Current forecasts for emissions from coal-based generation are simply incompatible with international efforts to avoid dangerous climate change. As the US is a major producer of coal-based power, American de-carbonization policy is therefore central to global efforts at reducing $\mathrm{CO} 2$ emissions.

\section{a. Coal-based emissions from US power}

The IEA WEO 2013 reports that the power sector accounted for 41.6 per cent of energy-based CO2 emissions in 2011 and that coal-based generation alone accounted for over 30 per cent. China was the world's largest emitter of CO2 from coal-based generation and the US was second. Looking forward, coal-based generation will grow fastest in China and India, but the US is also expected to be an important emitter of $\mathrm{CO} 2$ from coal-based generation at least over the next two decades.

The IEA forecast for US coal-based generation (Table 1) of 1351 million tonnes (Mt) in 2035, is based on the IEA 'New Policies Scenario', which assumes a continuation of current policies as of May 2013, and the implementation of policies that had been already announced. CO2 emissions would, however, be greater if the announced policies were not implemented; under the IEA's 'Current Policies Scenario', CO2 emissions from US coal-based generation would be $1815 \mathrm{Mt}$ - more than the 2011 level of $1716 \mathrm{Mt}$. The IEA also has a ' 450 Scenario' that reflects what would be required to have a 50 per cent chance of avoiding global temperature rises above $2^{\circ} \mathrm{C}$; in that scenario, coal-based generation in the US would emit less than 100 million tons of CO2 in 2035.

Table 1: World energy related CO2 emissions (Mt), 1990-2035 in IEA New Policies Scenario

$\begin{array}{crrr} & & & \text { Forecast } \\ & 1990 & 2011 & 2035 \\ \text { Total CO2 Emissions } & 20948 & 31161 & 37242 \\ \text { Of which coal-based generation } & 4915 & 9436 & 11000 \\ \text { USA } & 1550 & 1716 & 1351 \\ \text { China } & 597 & 3919 & 4991 \\ \text { India } & 215 & 837 & 1751\end{array}$

Source: IEA WEO 2013, pages 574, 586, 622, 626

Given the wide range of potential outcomes for coal consumption and related $\mathrm{CO} 2$ emissions in the US power sector, it is interesting to understand what to expect. The US EIA has forecast CO2 emissions from the power sector in its latest Annual Energy Outlook (AEO) 2014. In the AEO2014 Reference Scenario, CO2 emissions from the power sector are 2,247 Mt in 2035, with coal-based emissions of 1,643 Mt, slightly less than in 2011 and about $300 \mathrm{Mt}$ above the IEA 'New Policies Scenario'. 


\section{b. The challenge of lowering emissions at coal plants in the US}

In Graphic 1, it is noticeable that the total US capacity of coal-fired plants has been unchanged since the beginning of the 1990s (when the time series began), whereas gas-fired capacity grew rapidly after 1990. The average age of coal-fired plants is now over 40 years, while the average age of gasfired plants is closer to 15 years. The coal fleet includes very few modern plants with technologies like Integrated Gasification Combined Cycle (IGCC), or supercritical or ultra-supercritical plants. Efficiencies of average US coal-fired stations are low when compared to these best available technologies, which are commonly found in northern European countries and increasingly in China which has been closing inefficient old coal power stations and building efficient new ones at a remarkable rate for the past 15 years.

\section{Graphic 1: Electric net summer capacity, 1949-201111}

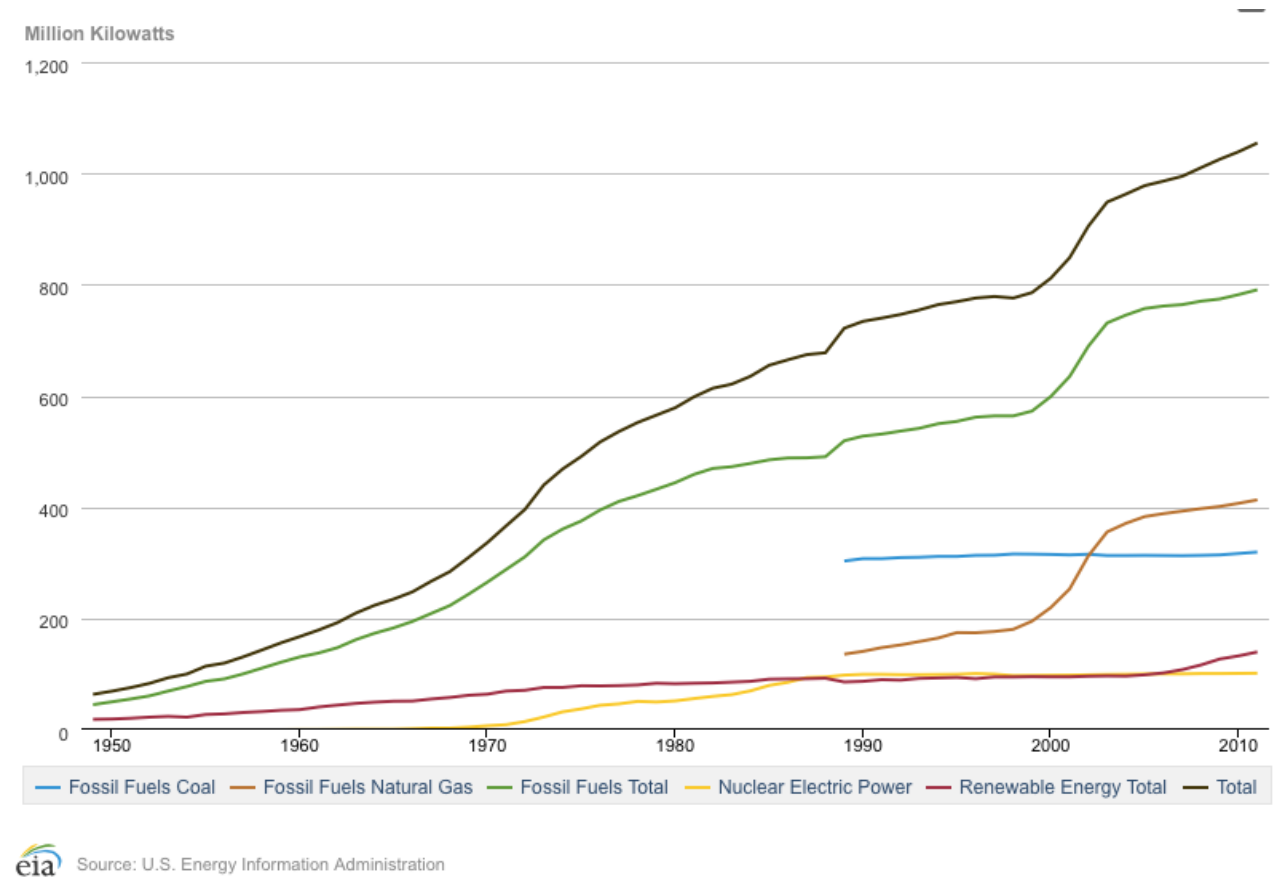

There are two technological solutions that have been adopted elsewhere to lower emissions from coal-based generation: close the old plants and wait for carbon capture and storage (CCS) technology to be commercially viable, as the UK is doing; or replace the old coal plants with new high efficiency ones, as China and Germany are doing. For reasons explained in this paper, the US will have trouble pursuing either of these options and could end up with a lot of old, inefficient coal plants and with related emissions barely falling, or perhaps even rising. Consistent with that view, the EIA 2014 AEO Reference Case sees coal consumption increasing in the power sector. 
That EIA Reference Scenario is based on current polices in 2013 and only indirectly reflects the possibility of the introduction of a price for carbon emissions in new plants (through a higher cost of capital for investment in coal-fired plants). It is also based on assumptions about the relative costs of gas and coal, demand growth and the future of renewables. It illustrates that prior to introducing specific regulations to curb $\mathrm{CO} 2$ emissions at power stations, the government forecast a rise in coalbased generation and related $\mathrm{CO} 2$ emissions.

This is in spite of four developments that have contributed to a reduction of coal-based generation and emissions in the US power sector since 2005: gas replacing coal in the power sector; the growth of renewable power; lower demand for electricity; and regulations to reduce emissions (especially at the state level). The remainder of the paper will explore these four issues, with the regulatory focus on the new EPA proposals.

\section{Competition between coal and natural gas}

For existing coal and natural gas power stations, the fuel price is the critical determinant of merit order operation. I look first at the basic economics that determine merit order dispatch, then at how changing fuel price differentials have influenced dispatch in recent years, and finally at how these differentials are changing and could affect dispatch in future.

\section{a. Merit order effect}

Each plant is different (in terms of its thermal efficiency, for example) and the mix of plants on each system is different, so the nature of competition between coal and natural gas will naturally differ from one system to the next. Generally, Combined-Cycle Gas Turbine (CCGT) plants are more efficient than coal-fired plants, but when the ratio of natural gas prices to coal prices is greater than a factor of about 1.5 (and there are no carbon fees), a typical CCGT plant has higher short-term dispatch costs than a typical coal-fired plant ${ }^{12}$. For instance, ignoring $\mathrm{CO} 2$ emission costs, when coal prices are $\$ 2.5 / \mathrm{MMBTU}$, efficient coal plants will normally be dispatched before natural gas plants when the price of natural gas rises above $\$ 4 / M M B T U$.

\section{b. Shift from coal to natural gas in 2008}

One of the fundamental changes in the US power sector, which also helps to explain the fall in $\mathrm{CO} 2$ emissions, is that coal has lost market share to natural gas since 2008. The EIA reports that coal accounted for between 48-51 per cent of US generation between 2001 and 2008, but only 37.5 per cent in 2012. Most of coal's decline took place after 2008, with the rise of natural gas based generation, whose market share rose from 22 per cent in that year to 30 per cent in 2012. In April 

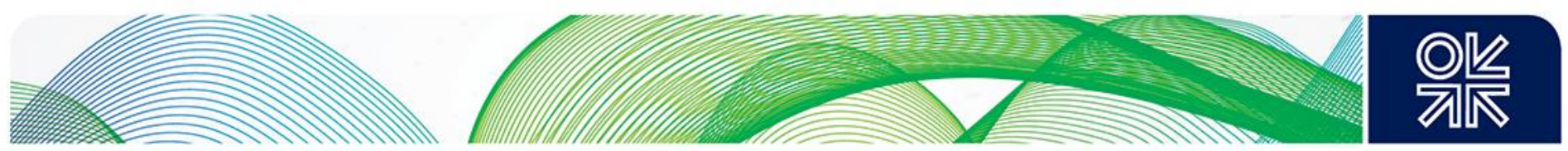

2012, coal-based plants and natural gas-based plants each accounted for about 32 per cent of generation output.

As background to understanding the recent increase in gas-fired generation, it is worth recalling some history - in particular why there was excess gas-fired capacity available to replace coal-fired generation in 2008. As Graphic 2 illustrates, the price of natural gas fell following deregulation of the gas sector in the 1980s.

\section{Graphic 2: History of US well-head natural gas prices, $1976-2012^{13}$}

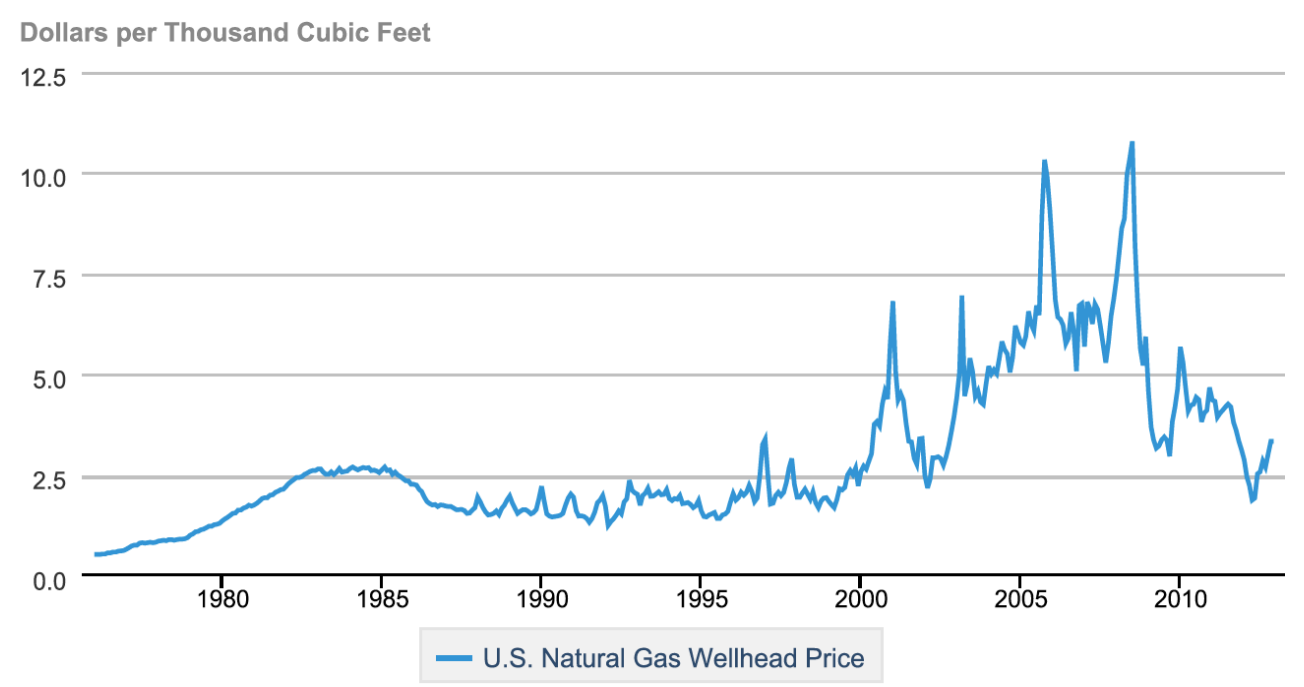

eia Source: U.S. Energy Information Administration

This decline in natural gas prices, along with the development of more efficient CCGT technology and electricity sector deregulation in the early 1990s, led to the building of a significant amount of gas-fired capacity in the 1990s and early 2000s, while coal-fired capacity remained almost unchanged (as illustrated in Graphic 1). However, in the early 2000s, natural gas prices started to rise and it became clear that sulfur emission limits for power stations could be met without the need for natural gas because of the availability of low-sulfur Powder River Basin coal. The result was excess capacity very low utilization - of natural gas-fired plants. Thus history reminds us of the importance of past investment decisions. Once power stations are built, their utilization depends heavily on comparative fuel prices and on environmental regulations.

The switch from coal to natural gas between 2008 and 2012 was directly related to the decline in natural gas prices, which in turn was due to the growth of unconventional natural gas. In 2012, for instance, natural gas prices were at their lowest levels since 1999 - an average of \$3.42/MMBTU, compared to prices of about \$7-9/MMBTU in 2007-08 (See Table 2). Coal prices, on the other hand, had risen from \$1.8-2.1/MMBTU in 2007-08 to $\$ 2.38 / \mathrm{MMBTU}$ in 2012. This, along with their relatively

${ }^{13}$ EIA, US Natural Gas Wellhead Price, http://www.eia.gov/dnav/ng/hist/n9190us3M.htm (last visited 18 April 2014). 
higher thermal efficiency, helped gas-fired plants' short-term dispatch costs to fall below those of most steam coal plants. Since there was an excess of gas-fired plants on many different regional systems, there were no major investment costs required for natural gas-fired plants to gain power market share; they simply ran more than they had previously because they were higher in the merit order.

Table 2: Average cost of fuels for US electric power industry 2002-2012 (\$/MMBTU) ${ }^{14}$

\section{COAL}

2002
2003
2004
2005
2006
2007
2008
2009
2010
2011
2012

2002

2003

2004

2005

2006

2007

2008

2009

2011

2012

1.25
1.28
1.36
1.54
1.69
1.77
2.07
2.21
2.27
2.39
2.38

1.25

1.36

1.54

1.69

1.77

2.07

2.21

2.27

2.38

\section{NATURAL GAS}

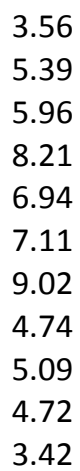

Table 3 summarizes the changing consumption of coal and natural gas in the US power sector between 2008 and 2012. Coal consumption in the sector fell by 21 per cent, from 1.04 billion tons to 825 million tons, while natural gas consumption for power rose 38 per cent, from 6.9 Tcf to 9.5 Tcf over the same period.

Table 3: Consumption of coal and natural gas in the US power sector, 2002-2012 ${ }^{15}$

$\begin{array}{lcl} & \begin{array}{l}\text { COAL } \\ \text { ('O00 tons) }\end{array} & \begin{array}{l}\text { NATURAL GAS } \\ \text { Millions cubic feet } \\ 2002\end{array} \\ 2087,583 & 6,126,062 \\ 2003 & 1,014,058 & 5,616,135 \\ 2004 & 1,020,523 & 5,674,580 \\ 2005 & 1,041,448 & 6,036,370 \\ 2006 & 1,030,556 & 6,461,615 \\ 2008 & 1,046,795 & 7,089,342 \\ 2009 & 1,042,335 & 6,895,843 \\ 2010 & 934,683 & 7,121,069 \\ 2011 & 979,684 & 7,680,185 \\ 2012 & 934,938 & 7,883,865 \\ & 825,734 & 9,484,710\end{array}$

The expansion of generation capacity provides further evidence of a shift towards gas and away from coal ${ }^{16}$. From 2000-2005, capacity growth was high, with about 35 GW of capacity built each year,

\footnotetext{
${ }_{14}$ Table 7.1 Receipts, Average Cost and Quality of Fuels for Electric Power Industry 2002-2012, ElA Electricity Annual 2012. http://www.eia.gov/electricity/annual/html/epa_07_01.html (last visited 29 March 2014).

${ }^{15}$ Table 1.2 Summary Statistics for the United States 2002-2012 (see Table on Consumption of Fossil Fuels) ElA Electricity Annual 2012. http://www.eia.gov/electricity/annual/html/epa 01 02.html (last visited 8 April 2014).
} 
most of which was gas-fired. Since then, generation capacity has grown more slowly, and included mainly wind power and natural gas plants. There has been relatively little investment in new coal-fired plants since 2000 .

\section{c. Shift back to coal in 2013}

Since 2012, the merit order effect has favored coal, prices for which fell in 2013 at the same time as prices for natural gas rose to $\$ 4 / \mathrm{MMBTU}$. Table 4 shows the impact of this changing price differential. In 2013, coal generated 40 per cent of US electricity, up from 37.5 per cent in 2012. Natural gas generated 28 per cent, compared to 30 per cent in $2012^{17}$.

Table 4: Electricity supply by fuel in 2011-2013 (billion kWh) ${ }^{18}$

$\begin{array}{lrrr} & \mathbf{2 0 1 1} & \mathbf{2 0 1 2} & \mathbf{2 0 1 3} \\ \text { Coal } & & & \\ \text { Petroleum } & 1,733 & 1,512 & 1,629 \\ \text { Natural Gas } & 30 & 23 & 21 \\ \text { Nuclear Power } & 1,014 & 1,228 & 1,117 \\ \text { Renewables } & 790 & 769 & 758 \\ \text { Other } & 517 & 502 & 525 \\ \text { TOTAL } & 19 & 19 & 17 \\ \text { NET TO GRID } & 4,103 & 4054 & 4,067 \\ & 3,976 & 3,915 & 3,921\end{array}$

Another example of the merit order effect and the return to coal was the impact of high natural gas spot prices in January 2014. In that month, Henry Hub prices reached over \$7.00/MMBTU on certain days, with much higher spot prices in markets in the northeast US. Table 5 illustrates that the average cost of natural gas rose 61 per cent between January 2013 and January 2014, while the unit cost of coal in the power sector had fallen slightly. 

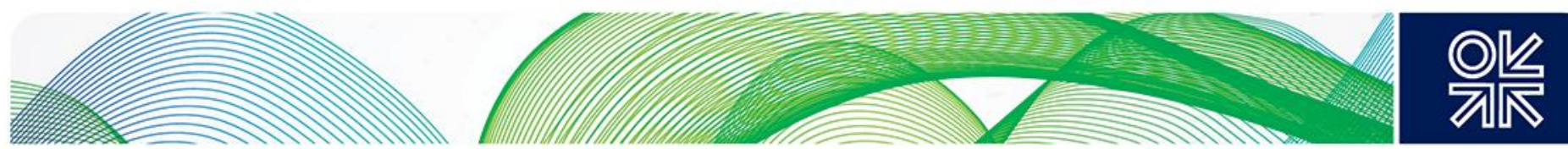

Table 5: Cost of fuels for electric power industry, January 2014 and January 2013 (\$/physical unit) ${ }^{19}$

$\begin{array}{lrrr} & \text { Jan-14 } & \text { Jan-13 } & \text { Change } \\ & & & \\ \text { Coal (1000 tons) } & 43,88 & 45,29 & -3 \% \\ \text { Natural Gas (1000 Mcf) } & 7,21 & 4,49 & 61 \%\end{array}$

The severe cold weather in January 2014 led to an increase in demand for electricity from all sources. Table 6 shows that coal-based generation increased more than 14 per cent compared to January 2013, while gas-based generation increased by less than 3 per cent. Over the same period, the monthly consumption of coal rose by 11.6 per cent and natural gas by only 4.3 per cent. In part, the lower growth for natural gas reflects natural gas pipeline restrictions.

Table 6: US Net generation and consumption of fuels for January 2013 and January $2014^{20}$

$\begin{array}{lrrr}\text { NET GENERATION (thousand MWh) } & \text { Jan-14 } & \text { Jan-13 } & \text { Change } \\ \text { COAL } & 157699 & 138265 & 14 \% \\ \text { NATURAL GAS } & 90489 & 88012 & 3 \% \\ \text { RENEWABLES excl hydro } & 25378 & 21452 & 18 \% \\ \text { NUCLEAR } & 73064 & 71406 & 2 \% \\ \text { OTHER } & 30389 & 29355 & 4 \% \\ \text { TOTAL } & 377019 & 348490 & 8 \%\end{array}$

\section{CONSUMPTION OF FOSSIL FUELS FOR ELECTRICTY GENERATION}

\author{
COAL (1000 tons) \\ NATURAL GAS (1000 mcf) \\ PETROLEUM LIQUIDS (1000 tons) \\ PETROLEUM COKE (1000 tons)
}

$\begin{array}{rrr}83710 & 74985 & 12 \% \\ 689214 & 660483 & 4 \% \\ 10375 & 2814 & 269 \% \\ 446 & 382 & 17 \%\end{array}$

\section{d. Anticipation that merit order effect will benefit coal}

There are reasons to expect the future price of natural gas to be higher (in real terms) than the spot prices of 2012, when they averaged \$3.42/MMBTU and were at times below \$3/MMBTU. These include the likelihood of rising demand for natural gas, including for exports, industrial uses, heating and power, as well as the view that the costs of sustainable exploration and production for shale gas in the US are higher than the prices of 2012. OIES experts have estimated that sustainable US

\footnotetext{
19 Table ES2.A Summary Statistics: Receipts and Cost of Fossil Fuels for the Electric Power Industry by Sector, Physical Units, 2014 and 2013 , EIA Electric Power Monthly, http://www.eia.gov/electricity/monthly/pdf/epm.pdf (last visited 29 March 2014). 20 Table ES1.A Total Electric Power Industry Summary Statististics, 2014 and 2013, ElA Electric Power Monthly, http://www.eia.gov/electricity/monthly/pdf/epm.pdf (last visited 29 March 2014).
} 
natural gas prices - bearing in mind the cost of exploration and development for shale gas - are in the range of $\$ 4-\$ 7 / M M B T U$, with the most likely outcome between $\$ 5-6 / M_{M B T U}{ }^{21}$. If this range is correct, and coal prices continue within their historic range of about $\$ 2-2.50 / \mathrm{MMBTU}$ in real terms, the differential will favor coal in the merit order.

It is interesting to look further and briefly at the impact of demand on the price of natural gas. A number of studies from consulting firms and the EIA found that for exports of 4-6 bcf/d of LNG, under reasonable market conditions, natural gas prices in 2035 would be between 2-11 per cent higher if the US does export LNG than if it does not ${ }^{22}$. The higher level reflects a fast ramp up of exports, which seems less likely now. Nevertheless, the prospect of exports and rising demand from other sectors probably explains why the EIA's AEO 2013 Reference Case (Graphic 3) assumes that natural gas prices will rise faster than coal prices.

Graphic 3: EIA AEO 2013: relative price of natural gas to coal in US $^{23}$

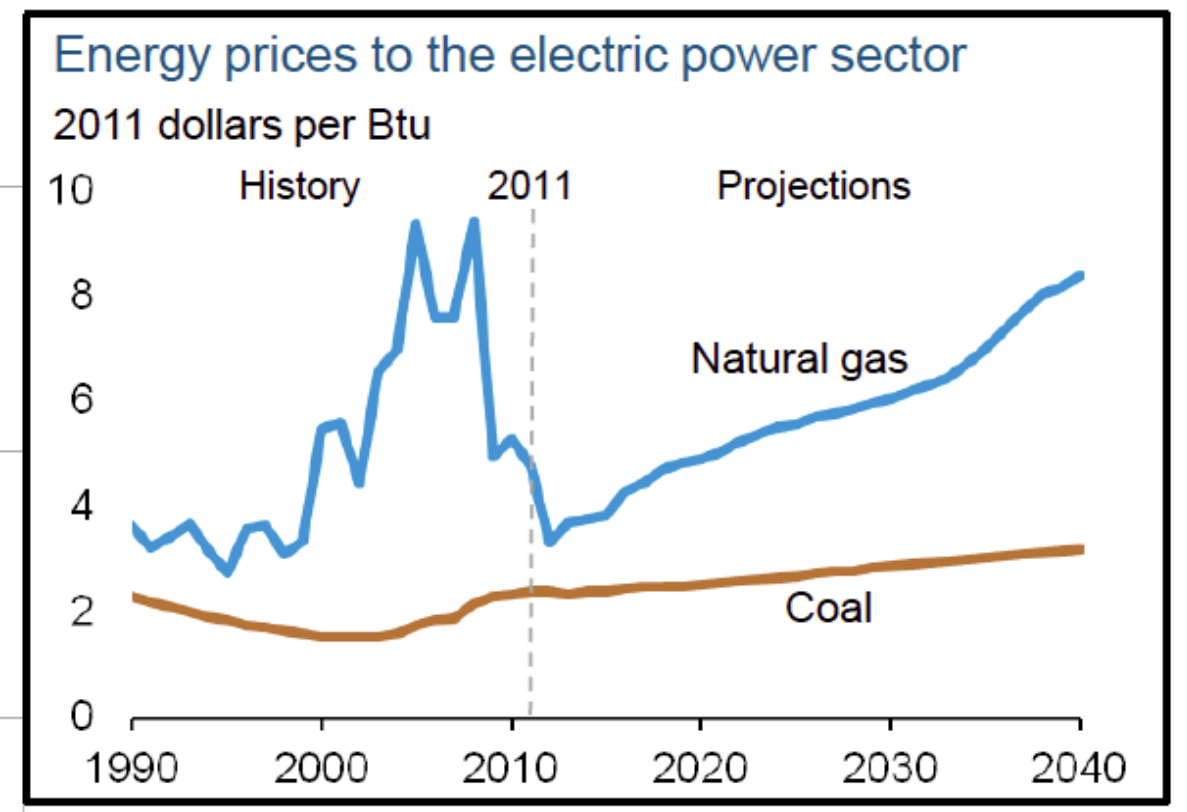

Furthermore, the EIA may underestimate the potential for coal-based generation by forecasting rising coal prices and gas prices that are decoupled from world oil and gas prices. ${ }^{24}$ The EIA forecasts for real coal prices have been rising in recent Annual Energy Outlooks (AEO). As late as AEO2010 the EIA expected real coal prices to remain flat at about $\$ 30 / t$ until 2035, but in AEO2012, their price forecast was almost $\$ 50 / t$ in 2035 and in AEO2014 it is $\$ 56 / t$ in 2035. This is despite ample US coal

\footnotetext{
${ }^{21}$ See James Henderson, The Potential Impact of North American LNG Exports, October 2012, OIES NG 68, pp. 45-46, http://www.oxfordenergy.org/wpcms/wp-content/uploads/2012/10/NG-68.pdf; and Howard Rogers, The Impact of Globalizing Market Supply on Future European Gas Supply and Pricing; the Importance of Asian Demand and North American Supply, OIES NG 59, January 2012, http://www.oxfordenergy.org/wpcms/wp-content/uploads/2012/01/NG 59.pdf.

${ }^{22}$ Charles Ebinger and Avinda Avasarala,"The Case for LNG Exports", Oxford Energy Forum 91, February 2013, pp. 6-8. ${ }^{23}$ US EIA, AEO 2013, Early Release. Presentation Adam Sieminski, December 5, 2012 http://www.eia.gov/pressroom/presentations/sieminski 12052012.pdf (last consulted April 18, 2014).

${ }^{24}$ See Prof. Denny Ellerman, "Decarbonization in the US and the EU", Advanced FSR Webinar, 9 October 2012 http://fsr.eui.eu/Publications/VIDEO/Webinar/2012/121009-WR-Ellerman.aspx
} 

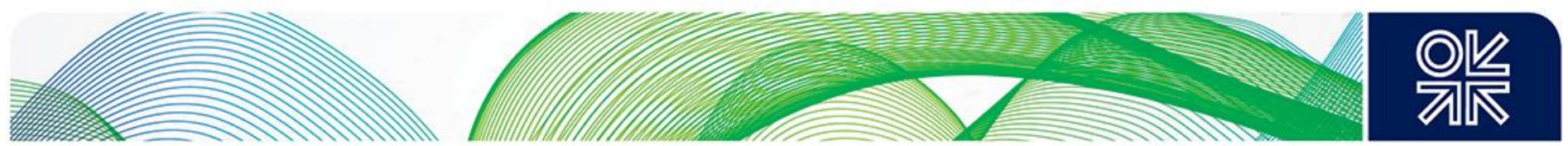

reserves and the fact that the EPA is introducing regulations that aim to reduce the use of coal at the point of consumption.

Meanwhile, the EIA forecasts for gas have been falling, reflecting the discoveries of shale gas. The AEO2008 forecast for 2035 was over $\$ 8 / \mathrm{Mcf}$, compared to the AEO2012 forecast of below $\$ 7 / \mathrm{Mcf}$ and the AEO2014 forecast of $\$ 7.1 / \mathrm{Mcf}$ in real terms. On the other hand EIA forecasts for real crude oil prices in 2030 have doubled, from about $\$ 60 / \mathrm{bbl}$ in the AEO2008 to over $\$ 120 / \mathrm{bbl}$ in AEO2012. The AEO2012 and AEO2014 price forecasts for imported crude oil in 2035 range between $\$ 120-\$ 130 / \mathrm{bbl}$. The implication is that US natural gas prices will be increasingly decoupled from world oil prices on a thermal basis (per Btu). In the AEO2014, US natural gas prices (per Btu) are forecast to be equal to only a quarter of world oil prices, compared to 70 per cent in the AEO2006. This forecast is despite the fact that internationally traded natural gas is usually indexed to oil prices, and it ignores both the US potential for significant LNG exports and the potential for natural gas to replace oil in the US in certain instances, such as heating and transportation.

It is of course possible that natural gas and coal prices will develop as forecast by the EIA or be less favorable to coal; tight restrictions on LNG exports and no restriction on coal exports could support that view. Nevertheless, I think it is reasonable not only to expect natural gas prices to rise faster than coal prices, but also to suggest that the price differential could favor coal even more than is predicted by the EIA in its Reference Scenario.

\section{e. Will EU experience be replicated?}

When the EU ETS was introduced, the expectation was that introducing a price for $\mathrm{CO} 2$ emissions would enable natural gas to replace coal in the merit order. Though this was initially the case, over the past few years the economics have changed. Coal prices have fallen, partly as a result of US coal exports, and the price of $\mathrm{CO} 2$ emission allowances has fallen dramatically due to a combination of the initial oversupply of allowances, the economic recession and the growth of renewable energy. The result has been an increase in the share of coal-based generation in the EU, especially in Germany and the UK. This has significantly reduced the expected demand for natural gas and made a large number of natural gas-fired plants unprofitable. Most experts expect a decline in coal-based generation in the medium term, mainly due to explicit EU regulations on emissions - in particular the Large Combustion Plant Directive and the Industrial Emissions Directive. Nevertheless, as long as dispatch is determined solely on the basis of marginal costs, coal is likely to remain at an advantage as long as gas prices are high and $\mathrm{CO} 2$ emissions prices are low.

This serves as an illustration of how the merit order could develop in the US, even if carbon emissions are priced. The pertinent questions for the future are: how the combination of these three prices (coal, gas, carbon emissions) will affect the merit order; how expectations over those prices will influence investment decisions; and whether other explicit regulations on $\mathrm{CO} 2$ emissions will outweigh the merit order logic.

In this section, I have concentrated on reasons why coal is likely to continue to generate an important part of US electricity, limiting the potential increase in the market share for natural gas. I would now like to explore two developments that will limit demand for both coal and natural gas in the power market and thereby reduce $\mathrm{CO} 2$ emissions: renewable energy and slow or negative electricity 
demand growth. Although these trends do not favor coal or gas, the relative impact on these two fossil fuels depends on their respective roles in the wholesale market.

\section{Renewable power}

\section{a. Growth of renewable electricity in the US}

The growth of renewable power reduces the demand for coal and gas-based generation. Graphic 4 reflects the fact that generation from 'other renewables' (non-hydro) is growing faster than any other source of generation. Over half of the incremental generation capacity added in the US in $2012^{25}$ comes from renewable power, and this reflects a growing trend that is expected to continue.

\section{Graphic 4: Net generation from different generation sources -2001 to $2014^{26}$}

\section{Net Generation for All Sectors, Monthly}

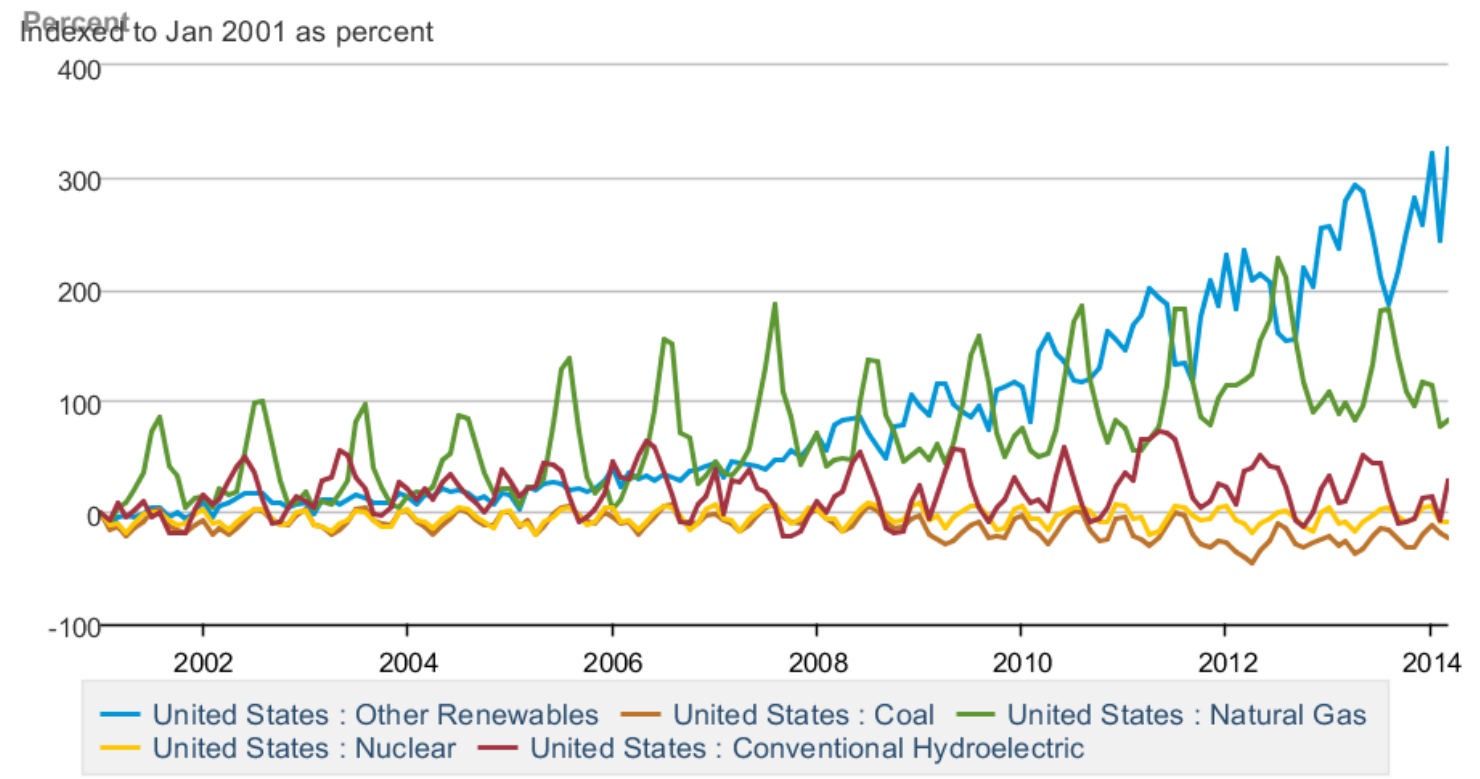

Data source: U.S. Energy Information Administration

\section{b. The EU experience with renewable power}

The European experience with renewable power is worth considering since it could be repeated in the US. In Europe, most of the renewable power capacity would not have been built without extra-market 

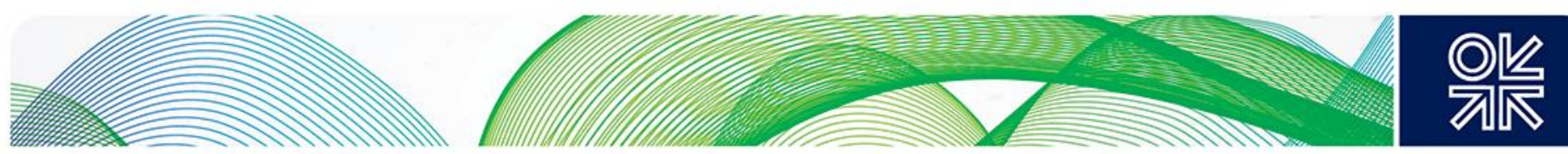

payments - in other words, financial support through feed-in tariffs or other mechanisms that supplemented wholesale market revenues. Renewables have had a profound effect on the role of conventional power stations and on the demand for coal and natural gas in the power sector. Renewable power has virtually zero marginal costs and, therefore, will almost always generate when the climatic conditions allow. Consequently, wind power and solar energy have displaced both coal and natural gas in the merit order of many EU countries, notably in Spain and Germany, which directly reduces the total demand for conventional fuels.

Furthermore, because wind and solar technologies are intermittent (generating only when the wind blows or the sun shines), they require backup to quickly increase or reduce generation to accommodate the renewables. This means that conventional power stations, especially CCGT, increasingly operate in a backup reserve capacity. Although this reserve service is valuable for the system and may be well remunerated, it does mean that the demand for fossil fuels is less than when conventional plants were operating to meet base-load. With respect to competition between natural gas and coal in the EU for the remaining market, the key is the relative prices of coal, gas and EU ETS emission permits: with coal prices and EU ETS emission permit prices very low and natural gas prices very high, coal has been gaining market share at the expense of natural gas.

It is conceivable that something similar could happen in the US. Already, renewable energy is growing extremely fast, partly as a result of federal renewable electricity production credits, but also due to the Renewable Portfolio Standards (RPS) that have been introduced in 35 states. These standards require the load serving entity (LSE) to supply at least a specified minimum amount of customer load with electricity from eligible renewable energy sources. RPSs initially specified a small percentage of the LSE supply, but have risen substantially and now range between 4 per cent and 30 per cent of electricity by a specified date ${ }^{27}$. As part of his Climate Action Plan, the President announced in June 2013 the intention to double US renewable generation by 2020; most of this would occur in any case under existing RPS regulations.

Growth of renewable energy is bad news for both coal and gas-fired plants, but the impact on each depends on the role they play in the wholesale market. In Europe, generation based on natural gas has tended to provide backup, whereas coal has been running on base-load due to the lower fuel costs and low $\mathrm{CO} 2$ emission prices. As mentioned earlier, the same could happen in the US if relative prices favor coal.

\section{Electricity demand growth (and distributed generation)}

\section{a. Electricity growth demand}

US electricity demand in 2013 is still below the 2007 level, as shown in Graphic 5. The question is whether electricity demand growth will recover or continue to stagnate, or fall. 


\section{Graphic 5: US retail sales of electricity, $2001-2013^{28}$}

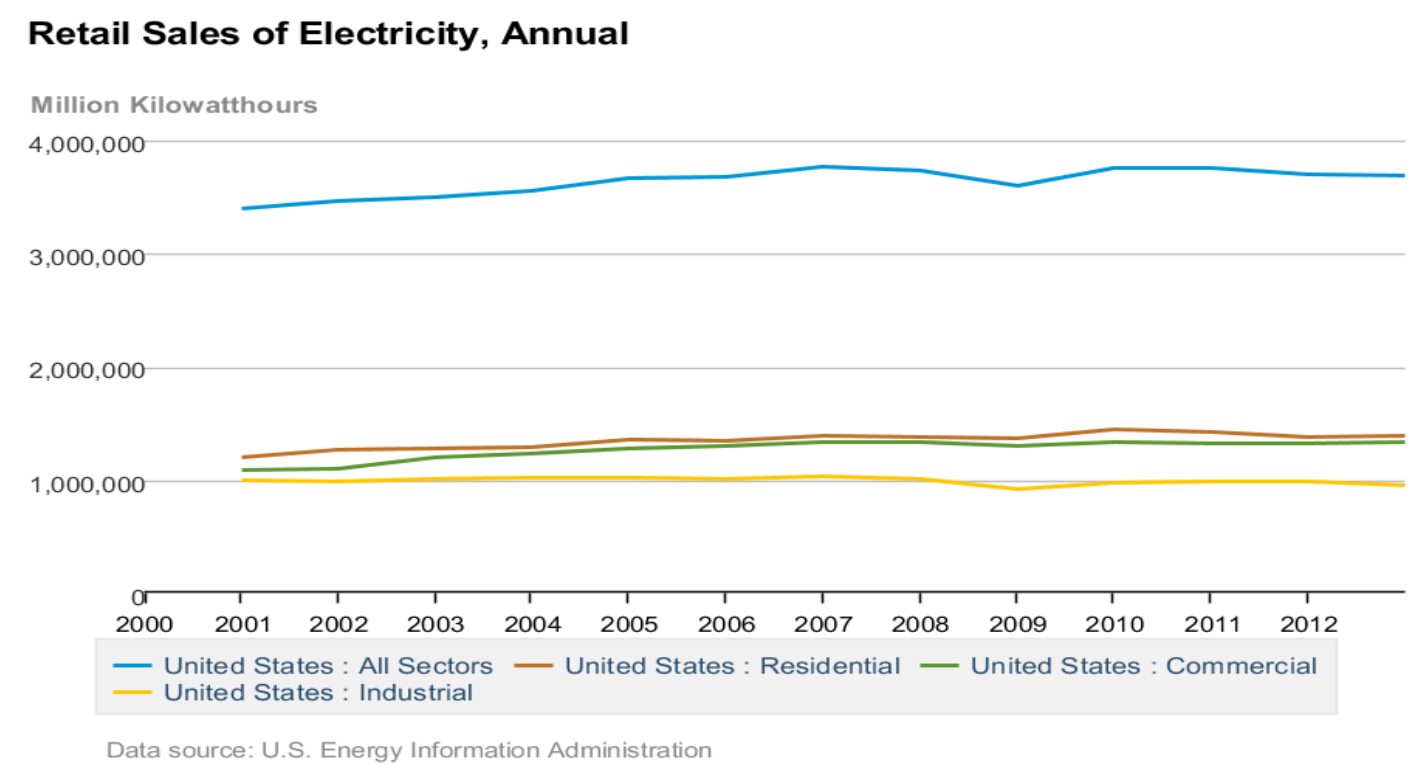

There are factors that support higher electricity demand growth in the longer term, for instance more electric vehicles and expectations of more robust economic growth. Yet, the increased emphasis on more efficient use of electricity and regulatory incentives to discourage consumption are unlikely to disappear. 25 states now have energy efficiency programs ${ }^{29}$ that generally encourage reduced electricity usage. For instance, in California, regulation now 'decouples' a utility's return on investment from its sales. In the past, the utility had an incentive to increase sales because, for any given set of regulated unit prices and fixed costs, higher sales meant higher profits; sales below forecast demand meant that fixed costs would not be recovered. Now, in many cases, the incentive structure positively encourages the utility to achieve lower sales than forecast. In addition, the EPA's recent proposals to reduce emissions from existing power stations imply an 11 per cent reduction in demand compared to business as usual forecasts for 2030.

\section{b. Distributed generation}

Distributed generation (DG) is often considered a 'negative demand' from the perspective of the overall electricity high voltage network. Growth of DG using renewable energy will reduce future network demand for generation from coal and natural gas. Consumers will produce their own electricity, for instance from solar panels. Though this is still a relatively small part of total generation in the US and EU systems, it is growing quickly and expected to continue growing, especially for solar PV (see graphic 6).

The attraction of DG to consumers depends on at least four factors: the cost of distributed generation and storage technologies; the level and design of electricity tariffs; the availability of metering and market designs to facilitate distributed generation and electricity sales by customers to the system; 
and financial support. The key developments over the past five years in the US and the EU have been the rapid decline in the cost of solar PV panels and the increase in the financial support and incentives for distributed generation. High volumetric tariffs (per kWh, with no fixed charges) have also contributed to DG. Although some factors - regulatory concerns about the recovery of stranded costs, leading to higher fixed charges - may weigh against DG, any forecast demand for natural gas and coal should factor in the growth of distributed generation.

\section{Graphic 6: Installed buildings, distributed generation capacity (GW) $)^{30}$}

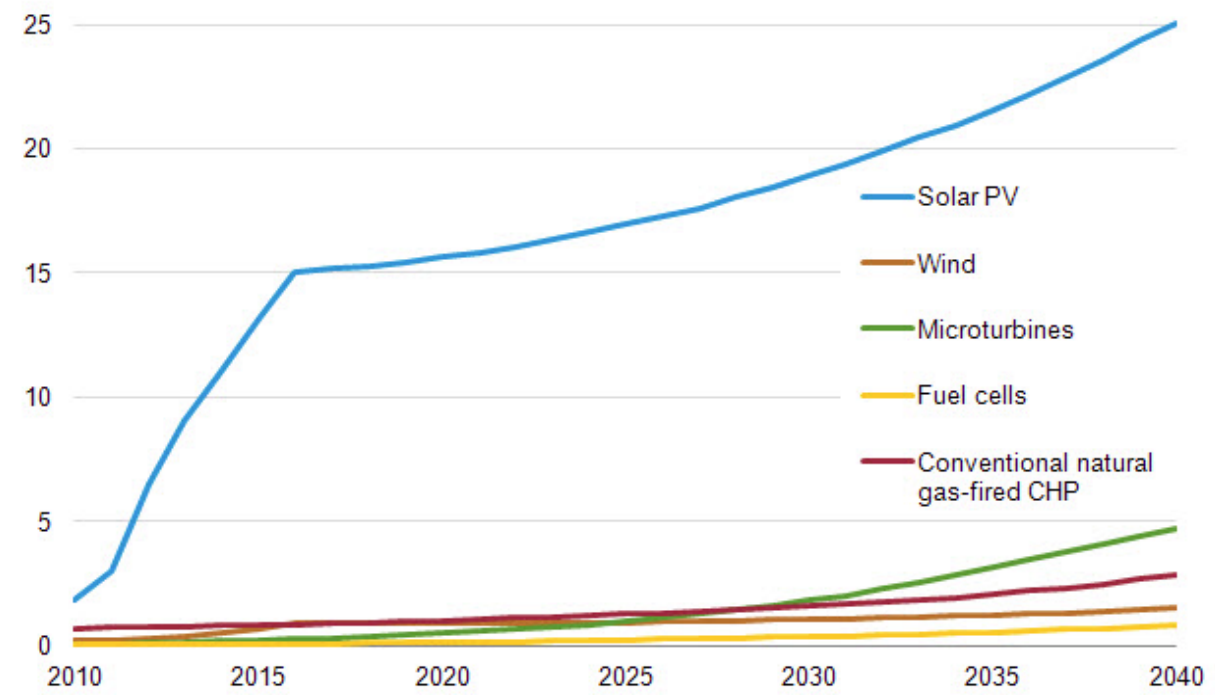

\section{EPA regulation of power sector emissions}

The EPA is responsible for the regulation of emissions from power stations, and critics maintain that the White House is using the agency to wage a 'war on coal'. Below, I consider existing regulations prior to the introduction of performance standards for $\mathrm{CO} 2$, as well as the EPA performance standards aimed at reducing $\mathrm{CO} 2$ emissions in the power sector.

\section{a. Existing non-CO2 regulations - MATS}

Coal-based generation is already being negatively affected by existing EPA regulations on conventional pollutants, in particular the emissions covered by MATS ${ }^{31}$. Operators are currently developing strategies to comply with MATS, which requires that coal-fired plants use the maximum achievable control technologies to control emissions of acid gases, toxic metals and mercury by April 

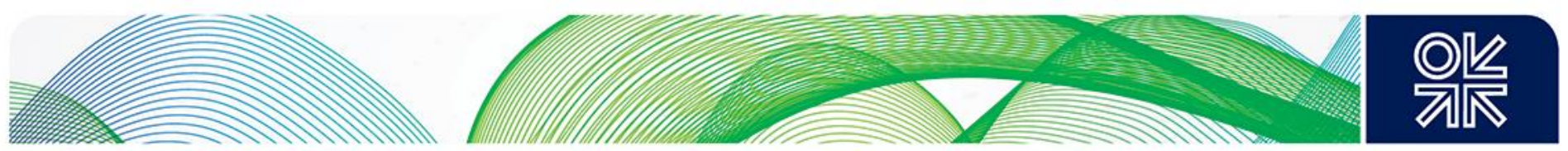

2015, with the possibility of a one-year extension. The costs to comply with MATS, including flue gas desulfurization (FGC) and dry sorbent injection (DSI), are significant and influence the decision to retrofit or to retire plants.

Faced with the costs of compliance with MATS, and potential costs of meeting other environmental regulations, many owners have announced their intention to shut plants. Of the existing coal-fired capacity of about $310 \mathrm{GW}$, The Brattle Group forecasts closure of between 59 GW and 77 GW - 1924 per cent of coal-fired capacity - by $2016^{32}$, depending on the stringency of the environmental requirements. This is consistent with the EIA 2014 Reference Case, which estimates that about 60 GW of coal plants will shut between 2012 and 2020.33

It should be noted that capacity additions before 2020 are not expected to be significant for coal, or for other types of generation, due to the existence of excess capacity on the system in many parts of the country.

\section{b. Introduction to $\mathrm{CO} 2$ performance standards}

The EPA's CO2 emission standards for power stations are sometimes portrayed as the critical battle in the 'war on coal'. Introducing CO2 emissions standards in the power sector will not be easy, especially for existing coal-fired power stations. This is in spite of a unanimous ruling from the D.C. Court of Appeals in 2012, which upheld the authority of the EPA to regulate GHG emissions under the Clean Air Act (CAA). That ruling put an end to a suit in which a coalition of states had challenged the EPA's 2009 finding that $\mathrm{CO} 2$ emissions endangered public health and should be regulated. Other recent court decisions have reinforced the EPA's authority to regulate $\mathrm{CO} 2$ emissions. While supporting the EPA authority to regulate $\mathrm{CO} 2$ emissions from power stations, judges on the Supreme Court have also indicated a concern that the EPA is trying to exceed its authority ${ }^{34}$. Furthermore, the EPA must go through a due process to justify the regulations that it introduces and this is where problems and delays may arise. Finally, there is strong political resistance - at the federal and state level - to the introduction of these regulations. The timetable and the challenges are different for new plants and for existing ones ${ }^{35}$.

\footnotetext{
32 Metin Celebi, Coal Plant Retirements and Market Impacts, February 5, 2014. http://www.brattle.com/system/publications/pdfs/000/004/982/original/Coal Plant Retirements and Market Impacts.pdf?1391 611874 (last visited 29 March 2014).

33 "Tougher EPA Rules Spark Rise in US Coal Plant Retirements", GTP Journal, 21 March 2014, p.5

34 "Supreme Court nibbles at EPA's greenhouse gas powers", http://www.politico.com/story/2014/06/supreme-court-epa-earlygreenhouse-gas-rules-108181.html\#ixzz35gLc30ew

35 This EPA webinar explains the process for regulating $\mathrm{CO} 2$ emissions at existing and new power stations, and provides details on some of the ways that Section 111 (d) of the Clean Air Act could be used to regulate existing power stations. http://www2.epa.gov/carbon-pollution-standards/what-epa-doing\#overview (last consulted, 12 April 2014).
} 


\section{c. CO2 standards for new power stations}

On 20 September 2013, the EPA Administrator Gina McArthy re-introduced CO2 performance standards for new power stations ${ }^{36}$. The new standards, which go into effect after one year, will distinguish between gas-fired and coal-fired power stations. New large gas-fired plants need to meet a limit of 1,000 pounds of CO2/MWh and the limit for new coal-fired units is 1,100 pounds/MWh; which translates into about $450 \mathrm{~kg} / \mathrm{MWh}$ for natural gas and $500 \mathrm{~kg} / \mathrm{MWh}$ for new coal. The view in the US appears to be that these standards would require the fitting of CCS equipment on new coalfired power stations.

According to the IEA, CO2 emissions for existing coal-fired plants in the US average over 900 $\mathrm{kg} / \mathrm{MWh}$, which is an illustration of how large the gap is between the new standard and actual emissions. For comparison, the new UK performance standard is $450 \mathrm{~kg} / \mathrm{MWh}$, a level that was intentionally set to allow natural gas-fired plants through without CCS, but to stop unabated coal. Another interesting comparison is with Denmark, which is best in class, with average emissions of $644 \mathrm{~kg} / \mathrm{MWh}$ for coal-fired plant. Admittedly, Denmark has access to lots of cold water for cooling purposes and uses a lot of the heat from these stations in combined heat and power (CHP). Nevertheless, the US should be able to replicate these conditions in at least some areas, especially since these Danish figures are averages and the Danes have not built new stations for some years.

The standards for new coal-based generation in the US are specific to the power station's own emissions. The EPA applies the principle of 'best system of emission reduction' (BSER), which the administration determines has been 'adequately demonstrated'. With current technology, this emission standard could be delivered at a new coal-fired power station fitted with CCS equipment, while not adopting CCS from the outset will mean a tougher standard. Critics argue that these standards rule out new coal-based generation, and that because CCS is not yet commercially available, it cannot be considered 'adequately demonstrated'. Disagreement on this issue could lead to litigation. ${ }^{37}$

In practice, the debate over EPA regulations for new plants is unlikely to affect whether new coal plants are built in the near term because demand is growing so slowly that new capacity is not required in most regions. More importantly, the emission standards established for existing plants are very unlikely to be more stringent than they are for new plants. This suggests that the battle being fought over new plant emission standards is probably about influencing what the standards will be for existing power stations.

\footnotetext{
36 See the EPA website for details. http://www2.epa.gov/carbon-pollution-standards/2013-proposed-carbon-pollution-standardnew-power-plants. The EPA initially proposed emission standards in 2012. The new standards take into account responses to the initial proposal.

${ }^{37}$ http://www.martenlaw.com/newsletter/20131118-regulations-co2-emissions-power-plants
} 


\section{d. CO2 standards for existing power stations}

On 2 June 2014 the EPA issued its proposed performance standards for reducing $\mathrm{CO} 2$ emissions in the power sector, under Section 111 (d) of the $\mathrm{CAA}^{38}$. The rule requires states to reduce the CO2 emissions rate (lbs. CO2/MWh) for existing fossil fuel-fired power stations to meet state-specific performance standards. The EPA estimates that the rule will result in a 30 per cent reduction in CO2 emissions in the power sector in 2030, compared to 2005 levels. The EPA identifies two options that it is still considering: option 1 involves a more stringent target for 2030, with an interim rate between 2020-2029; and option 2 has a less stringent target for 2025, with an interim rate for 2020-2024. It also refers to two compliance alternatives: the non-cooperative approach, in which a state meets its own target; and the multi-state approach where states cooperate to meet their targets together. The EPA will finalize the standards in June 2015. The states are then required to submit initial implementation proposals by 30 June 2016, to be finalized by June 2017 for state-specific plans and by June 2018 for multi-state plans.

\section{i. $\quad$ Background to the EPA proposal ${ }^{39}$}

The procedures for regulating existing plants are different than those that apply for new plants, and plants requiring substantial modifications. Under Section 111 (b) of the CAA, the EPA defines the plant-specific standards that will apply to new plants throughout the country. For existing plants, under Section 111 (d) of the CAA, the EPA issues guidelines about the appropriate standards, but the states are responsible for establishing and eventually implementing the performance standards, once they have been approved by the EPA. This difference in approach reflects the view that existing power stations face greater restrictions and higher costs in meeting emission standards than new plants do. The EPA guidelines define the BSER, the achievable emission limitations, the time requirements and the goal for reductions based on the BSER. The states then have flexibility to develop a plan that is 'equivalent' to the EPA standard.

The EPA has defined a different performance rate for each state, based on applying four 'building blocks' to each state. Below, for each building block, I have included the EPA's estimates of the cost of abatement per avoided ton of $\mathrm{CO} 2$, as well as the percentage of total $\mathrm{CO} 2$ abatement expected to come from each block on a national basis ${ }^{40}$.

- Improved efficiency of existing coal plants. The EPA assumes all coal plants will increase heat rates by 6 per cent. This accounts for 12 per cent of the BSER CO2 reductions, at a cost of $\$ 6-12 / \mathrm{tCO} 2$.

- Re-dispatch of existing plants from coal to CCGT. The EPA assumes all CCGT will operate up to a 70 per cent capacity factor and displace higher emitting generation, including coal and gas steam units. This re-dispatch accounts for 31 per cent of the forecast $\mathrm{CO} 2$ reductions, at a cost of $\$ 30 / \mathrm{tCO} 2$.

\footnotetext{
${ }^{38}$ For the regulation and relevant documention, see http://www2.epa.gov/carbon-pollution-standards/clean-power-planproposed-rule (last consulted 20 June 2014)

${ }^{39}$ For an excellent analysis of the economics of the proposed plan, see the Brattle Group's Policy Brief, "EPA's Proposed Clean Power Plan", June 2014, which can be found on their website:

http://www.brattle.com/system/publications/pdfs/000/005/025/original/EPA's_Proposed_Clean_Power_Plan_.

Implications_for_States_and_the_Electric_Industry.pdf?1403103925\%2011: Hereafter, I refer to it as the "Brattle Policy Brief".

${ }^{40}$ Brattle Policy Brief, pp. 3-4.
} 
- Increased renewable generation and new or retained 'at risk' nuclear plants. Additional nuclear generation accounts for 7 per cent of the BSER reductions at a cost of $\$ 12-\$ 17 / \mathrm{tCO}$. This assumes that nuclear plants at risk of closure remain open. Additional renewables account for 33 per cent of the CO2 reductions, at a cost of $\$ 10-40 / t C O 2$. There are 6 regional renewable growth targets.

- Increased energy efficiency on the demand side. The EPA assumes that each state increases efficiency by 0.2 per cent per annum from 2017, until they reach a maximum of 1.5 per cent, which continues until 2030. This accounts for 18 per cent of the BSER CO2 reductions and the estimated cost is $\$ 16-24 / \mathrm{tCO} 2$.

The EPA translates these building blocks into a different performance rate for each state. The starting point is the 2012 average rate of emissions from fossil fuel-powered generation in the state, measured as the aggregate $\mathrm{CO} 2$ emissions from fossil fuel-fired plants (electricity generating units, or EGU's) divided by aggregate generation (MWh). The EPA applies the first two building blocks; the resulting reduction in $\mathrm{CO} 2$ emissions lowers the numerator in the performance rate formula (see below). The EPA then applies the two other building blocks, which lower the rate by adding incremental zero-carbon generation and incremental demand reduction to the denominator. The formula includes generation from existing renewable stations in the denominator, but not generation from existing nuclear stations (apart from the 'at risk' nuclear).

The 2030 Performance rate for a given state $=$

CO2 from fossil EGU / MWh from fossil EGU + new and at risk nuclear + existing and new renewables + new energy efficiency

The states have flexibility to decide how to comply with the new performance standard. The list of possibilities for compliance identified by the EPA include:

- demand-side efficiency or energy conservation programs

- renewable energy standards

- efficiency improvements at plants

- co-firing or switching to natural gas

- transmission efficiency improvements

- energy storage technology

- retirements

- expanding nuclear or renewable capacity

- market-based trading mechanisms.

States that chose to do so could enable existing coal plants to operate even if they far exceeded unitspecific emission standards applying to new plants. 


\section{ii. Key messages ${ }^{41}$}

This is a long and complex piece of regulation ${ }^{42}$ that will require detailed analysis by each state, and by the affected parties therein. For the purpose of this paper, there are three important messages. First, the anticipated CO2 emissions are modest, at least from a European perspective. Second, there is significant uncertainty about the allocation of the compliance burden and potential for controversy over this allocation. Third, with this rule, the EPA expects fossil fuels to continue to play the dominant role in the US electricity system until at least 2030, with coal and natural gas each generating at least 30 per cent of US electricity. However, the forecast decline in electricity demand limits markets for both fossil fuels.

\section{Modest ambition}

The EPA estimates that in 2030 emissions will have fallen by 30 per cent compared to 2005 levels, and by 25 per cent compared to an assumed business as usual (BAU) case. Because emissions from the power sector have already fallen since 2005 , the implied reduction is about 18 per cent compared to 2012 levels. This leaves most of the heavy lifting for later and for other countries if the world is to meet the unofficial global objective of reducing greenhouse gases by over 80 per cent by 2050 , compared to 1990 levels. Not many countries have committed to achieving this target, but some have. For instance, the EU has a political target (not yet binding) to reduce greenhouse gas emissions by 80-95 per cent by 2050 , and a binding target to reduce them by 40 per cent by 2030 , in both cases compared to $1990^{43}$. The UK has a legally binding target to reduce them by 80 per cent by 2050 , against the 1990 level. Since electricity is expected to deliver a large share of the reductions, the implied reductions in $\mathrm{CO} 2$ emissions from the power sector are significantly greater than these average percentages suggest.

A better way to measure US ambition for the power sector is to compare it with power sector carbon intensity targets in other countries that are committed to de-carbonization, and where coal has played an important role. The EPA emission standard is not a conventional carbon intensity measure because it includes 'beyond the fence' measures, such as reduced demand. A more conventional measure divides total generation by total emissions, and on that basis, under the EPA forecasts, the carbon intensity rate will fall 19 per cent from about $1100 \mathrm{lbs} / \mathrm{MWh}(500 \mathrm{~kg} / \mathrm{MWh})$ in 2012 to about $890 \mathrm{lbs} / \mathrm{MWh}(400 \mathrm{~kg} / \mathrm{MWh})$ in 2030 , which is approximately the emissions rate of a conventional CCGT $^{44}$. By contrast, the UK Climate Change Committee uses scenarios to lower 'grid intensity' of the generation fleet from about $500 \mathrm{~kg} / \mathrm{MWh}$ to $50 \mathrm{kG} / \mathrm{MWh}$ by $2030^{45}$. Although the UK Government has not yet formally adopted a carbon intensity target, its Energy Market Reform package implicitly assumes an intensity target of $100 \mathrm{~kg} / \mathrm{MWh}$ by 2030. Furthermore, if the EPA estimates are reasonably accurate, the eventual US compliance cost of $\$ 8.8$ billion in 2030 is significantly less than the current cost of supporting de-carbonization in Germany alone. Even the UK will soon be close to the US figure for 2030. That suggests that the compliance costs of the EPA proposals are very low indeed.

\footnotetext{
${ }^{41}$ Another important message, not covered here, has to do with the economic costs and benefits of the EPA proposals. See Robert Stavins, "What are the Benefits and Costs of the EPA's Proposed CO2 Regulation?", June 19, 2014. http://www.robertstavinsblog.org

${ }^{42}$ The EPA's proposed carbon emission guidelines for existing electricity stations is 645 pages long and the impact analysis is 376 pages long.

${ }^{43}$ http://ec.europa.eu/clima/policies/brief/eu/index en.htm

${ }_{44}^{4}$ Brattle Policy Brief, pp. 5-6.

${ }^{45}$ http://www.theccc.org.uk/wp-content/uploads/2013/12/1785b-CCC TechRep Singles Chap2 1.pdf
} 

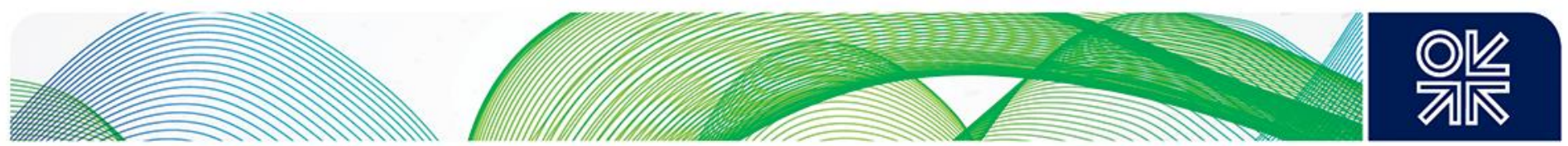

\section{Burden sharing}

First, the EPA estimates carbon avoidance costs of between $\$ 15-17 / \mathrm{tCO} 2$. This is based on simplifying and questionable assumptions, for instance that all states in a region have the same potential to develop renewable resources and that the probability of nuclear retirement is identical for all plants.

Second, the emission reductions and the cost of compliance will vary substantially from state to state, and the burden will not be shared simply by reference to percentage reductions in $\mathrm{CO} 2$, or even absolute reductions. States with very high rate reductions may be able to meet their targets through already planned retirement of one or two old coal plants. Nevertheless, it is interesting to compare states by reference to the proposed reductions in percentage and absolute terms. Although the average $\mathrm{CO} 2$ reduction is 25 per cent nationally, the EPA projects that 15 states (mainly heavily coal dependent) will reduce emissions by less than 15 per cent, and that another 15 states (mostly with abundant hydro, gas and coal plants) will reduce emissions by more than 35 per cent. By reference to $\mathrm{CO} 2$ tonnage, 6 states account for almost half of the $\mathrm{CO} 2$ reduction, and Texas alone accounts for 19 per cent ${ }^{46}$. The allocation reflects the EPA's view on the potential to abate emissions by reducing emissions at coal plants through re-dispatch of natural gas plants and with other low-carbon sources. Fundamentally, the states with the heaviest burden are those with high emission reduction targets and few low-cost abatement alternatives.

It is worth insisting on the difference in the burden among states. For instance, Minnesota and Missouri both have virtually the same fossil emission rates in 2012 (2010 lbs/MWh), but very different targets for 2030: $870 \mathrm{lbs} / \mathrm{MWh}$ for Minnesota and $1540 \mathrm{lbs} / \mathrm{MWh}$ for Missouri. The difference is due to Minnesota's larger renewable target and because the EPA assumes the state can use CCGT technology to displace coal. One state, Vermont, has no target rate because it has no fossil fuel plants, even though it relies on surrounding states for its power and would not be able to meet demand without access to such plants in the other states ${ }^{47}$.

The difference in burden sharing will naturally be a concern for those states with the heaviest burden. For example, the EPA has assumed that all states within a given region (of which there are six) have the same potential for renewable energy. In practice, states have different definitions of 'renewable' and different potential and costs for expanding renewable power. Another example is that the EPA has assumed that all nuclear plants 'at risk' of early retirement can increase production by 5.8 per cent, even though the costs and technical conditions vary significantly.

The EPA proposals will also have very different impacts on prices across the country. Brattle estimates that the effect on the marginal electricity price would be about $\$ 14 / \mathrm{MWh}$ where natural gas is at the margin and $\$ 35 / \mathrm{MWh}$ where coal is at the margin. Furthermore, there could be quite significant differences between neighboring states. This would be relatively easy to manage within existing wholesale markets that include both states, but otherwise be more difficult. Indeed, there may be incentives to generate electricity from inefficient coal plants in states with low abatement targets, and to shut down more efficient coal plants in states with high abatement targets ${ }^{48}$.

\footnotetext{
${ }^{46}$ Texas (19\%), Florida (8\%), Georgia (6\%), Pennsylvania (5\%), Arkansas (5\%) and West Virginia (5\%). Brattle Policy Brief, p.9. 
The EPA proposals also affect the producers of coal and gas. For instance, there are 25 states that produce coal ${ }^{49}$, and in 2012 some 80 per cent of US coal output was produced in Wyoming, West Virginia, Kentucky, Pennsylvania, Illinois, Texas, Indiana and Montana. The impact analysis of the proposed EPA performance standards identifies the expected regional impact on coal production; namely a 25 per cent fall in 2020 compared to the base case. The largest reduction in absolute terms (138 million tons) would occur in the West, but there would also be a significant (37 per cent) reduction in the Appalachia region. It is likely that the affected states will strongly contest these reductions and at least seek compensation.

\section{Graphic 7: EPA forecasts for coal production if proposals on $\mathrm{CO} 2$ emissions are adopted ${ }^{50}$}

Table 3-15. Coal Production for the Electric Power Sector, 2020

\begin{tabular}{|c|c|c|c|c|c|c|c|c|c|}
\hline & \multicolumn{5}{|c|}{ " Coal Production (MM Tons) } & \multicolumn{4}{|c|}{ Percent Change from Base Case } \\
\hline & \multirow{2}{*}{$\begin{array}{l}\text { Base } \\
\text { Case }\end{array}$} & \multicolumn{2}{|c|}{ Option 1} & \multicolumn{2}{|c|}{ Option 2} & \multicolumn{2}{|c|}{ Option 1} & \multicolumn{2}{|c|}{ Option 2} \\
\hline & & Reg. & State & Reg. & State & Reg. & State & Reg. & State \\
\hline Appalachia & 140 & 87 & 91 & $\mathrm{n} / \mathrm{a}$ & $\mathrm{n} / \mathrm{a}$ & $-37 \%$ & $-35 \%$ & $\mathrm{n} / \mathrm{a}$ & $\mathrm{n} / \mathrm{a}$ \\
\hline Interior & 249 & 231 & 222 & $\mathrm{n} / \mathrm{a}$ & $\mathrm{n} / \mathrm{a}$ & $-7 \%$ & $-11 \%$ & $\mathrm{n} / \mathrm{a}$ & $\mathrm{n} / \mathrm{a}$ \\
\hline West & 446 & 308 & 292 & $\mathrm{n} / \mathrm{a}$ & $\mathrm{n} / \mathrm{a}$ & $-31 \%$ & $-34 \%$ & $\mathrm{n} / \mathrm{a}$ & $\mathrm{n} / \mathrm{a}$ \\
\hline Waste Coal & 9 & 10 & 10 & $\mathrm{n} / \mathrm{a}$ & $\mathrm{n} / \mathrm{a}$ & $8 \%$ & $5 \%$ & $\mathrm{n} / \mathrm{a}$ & $\mathrm{n} / \mathrm{a}$ \\
\hline Imports & 0 & 0 & 0 & $\mathrm{n} / \mathrm{a}$ & $\mathrm{n} / \mathrm{a}$ & & & $\mathrm{n} / \mathrm{a}$ & $\mathrm{n} / \mathrm{a}$ \\
\hline Total & 844 & 636 & 616 & $\mathrm{n} / \mathrm{a}$ & $\mathrm{n} / \mathrm{a}$ & $-25 \%$ & $-27 \%$ & $\mathrm{n} / \mathrm{a}$ & $\mathrm{n} / \mathrm{a}$ \\
\hline
\end{tabular}

Source: Integrated Planning Model run by EPA, 2014

Third, apart from burden sharing across states, each state will need to address the issues of burden sharing among the different parties within the state, in particular among the electricity generators and their customers.

The message on burden sharing is that the EPA regulations will create significant controversy among and within states, and between the states and the EPA. Though the EPA recognizes that this will be a complex and long process, some parties will consider the burden to be unacceptable and are likely to challenge the final regulations (June 2016) politically and in the courts.

\section{Dominant role for fossil fuels}

The impact on coal-based and gas-based generation will depend on the measures adopted, but it is clear that the EPA expects these fuels to dominate the power sector at least until 2030. The EPA estimates a 25 per cent decline in coal-based generation in 2030, compared to its base case, partly due to lower electricity demand ( 11 per cent compared to the base case) and replacement by natural gas. However, EPA still projects that coal will account for $1249 \mathrm{GWh}$ in 2030 , compared to $1478 \mathrm{GWh}$ in 2012 and 1590 GWh in 2013, a decline of 15-21 per cent depending on the base year. Even with that decline, EPA projects that coal would be generating more than 30 per cent of US electricity in 2030. 
Graphic 8: EPA estimates of US generation mix with EPA proposed performance standard $(\mathrm{GWh})^{51}$

\begin{tabular}{lccccc|cccc}
\hline Pulverized Coal & 1,668 & 1,249 & 1,216 & $\mathrm{n} / \mathrm{a}$ & $\mathrm{n} / \mathrm{a}$ & $-25 \%$ & $-27 \%$ & $\mathrm{n} / \mathrm{a}$ & $\mathrm{n} / \mathrm{a}$ \\
$\begin{array}{l}\text { NG Combined Cycle } \\
\text { (existing) }\end{array}$ & 810 & 955 & 961 & $\mathrm{n} / \mathrm{a}$ & $\mathrm{n} / \mathrm{a}$ & $18 \%$ & $19 \%$ & $\mathrm{n} / \mathrm{a}$ & $\mathrm{n} / \mathrm{a}$ \\
$\begin{array}{l}\text { NG Combined Cycle } \\
\text { (new) }\end{array}$ & 599 & 359 & 384 & $\mathrm{n} / \mathrm{a}$ & $\mathrm{n} / \mathrm{a}$ & $-40 \%$ & $-36 \%$ & $\mathrm{n} / \mathrm{a}$ & $\mathrm{n} / \mathrm{a}$ \\
Combustion Turbine & 23 & 32 & 31 & $\mathrm{n} / \mathrm{a}$ & $\mathrm{n} / \mathrm{a}$ & $43 \%$ & $35 \%$ & $\mathrm{n} / \mathrm{a}$ & $\mathrm{n} / \mathrm{a}$ \\
Oil/Gas Steam & 23 & 10 & 12 & $\mathrm{n} / \mathrm{a}$ & $\mathrm{n} / \mathrm{a}$ & $-57 \%$ & $-46 \%$ & $\mathrm{n} / \mathrm{a}$ & $\mathrm{n} / \mathrm{a}$ \\
Non-Hydro Renewables & 350 & 356 & 356 & $\mathrm{n} / \mathrm{a}$ & $\mathrm{n} / \mathrm{a}$ & $2 \%$ & $2 \%$ & $\mathrm{n} / \mathrm{a}$ & $\mathrm{n} / \mathrm{a}$ \\
Hydro & 280 & 281 & 280 & $\mathrm{n} / \mathrm{a}$ & $\mathrm{n} / \mathrm{a}$ & $0 \%$ & $0 \%$ & $\mathrm{n} / \mathrm{a}$ & $\mathrm{n} / \mathrm{a}$ \\
Nuclear & 797 & 796 & 797 & $\mathrm{n} / \mathrm{a}$ & $\mathrm{n} / \mathrm{a}$ & $0 \%$ & $0 \%$ & $\mathrm{n} / \mathrm{a}$ & $\mathrm{n} / \mathrm{a}$ \\
Other & 6 & 16 & 14 & $\mathrm{n} / \mathrm{a}$ & $\mathrm{n} / \mathrm{a}$ & $163 \%$ & $132 \%$ & $\mathrm{n} / \mathrm{a}$ & $\mathrm{n} / \mathrm{a}$ \\
Total & 4,557 & 4,054 & 4,051 & $\mathrm{n} / \mathrm{a}$ & $\mathrm{n} / \mathrm{a}$ & $-11 \%$ & $-11 \%$ & $\mathrm{n} / \mathrm{a}$ & $\mathrm{n} / \mathrm{a}$
\end{tabular}

Although natural gas displaces coal in the EPA forecasts and is higher in the base case until 2025, total generation from gas-fired plants falls 5.3 per cent by comparison to the base case for 2030, mainly due to the impact of lower forecast electricity demand. Existing gas-fired plants generate more, but fewer new plants are built ${ }^{52}$. Gas-fired generation would account for 32 per cent of generation in 2030. The 2030 forecast for natural gas use in the power sector is $9.39 \mathrm{Tcf}$, compared to $9.25 \mathrm{Tcf}$ in 2012 and 8.13 in $2013^{53}$.

\section{Graphic 9: EPA estimate for power sector gas use with EPA proposed performance standard ${ }^{54}$}

Table 3-16. Power Sector Gas Use

\begin{tabular}{|c|c|c|c|c|c|c|}
\hline & \multicolumn{3}{|c|}{ Power Sector Gas Use (TCF) } & \multicolumn{3}{|c|}{$\begin{array}{c}\text { Percent Change in Power Sector Gas } \\
\text { Use }\end{array}$} \\
\hline & 2020 & 2025 & 2030 & 2020 & 2025 & 2030 \\
\hline Base Case & 8.35 & 8.88 & 9.89 & & & \\
\hline Option 1 Regional & 9.32 & 9.31 & 9.37 & $11.7 \%$ & $4.8 \%$ & $-5.3 \%$ \\
\hline Option 1 State & 9.54 & 9.52 & 9.61 & $14.3 \%$ & $7.2 \%$ & $-2.9 \%$ \\
\hline Option 2 Regional & 9.20 & 9.34 & $\mathrm{n} / \mathrm{a}$ & $10.2 \%$ & $5.1 \%$ & $\mathrm{n} / \mathrm{a}$ \\
\hline Option 2 State & 9.35 & 9.52 & $\mathrm{n} / \mathrm{a}$ & $12.0 \%$ & $7.2 \%$ & $\mathrm{n} / \mathrm{a}$ \\
\hline
\end{tabular}

Source: Integrated Planning Model run by EPA, 2014

\section{iii. Two different interpretations}

There are broadly two different schools of thought with regard to the prospects for these proposed regulations. One is that the process will proceed as planned. In the best case, it will lead to a 'tradable performance standard' that moves the country in the direction of emissions trading and a national carbon price. On that interpretation, as long as federal climate change legislation is impossible to pass and EPA regulations are the 'only game in town', the agency's proposals are

\footnotetext{
${ }^{51}$ EPA "Regulatory Impact Analysis for Carbon Pollution Regulations for Existing Power Plants", June 2014, p. 3-36. 52 See the EPA's Regulatory Impact Analysis for the Proposed Carbon Pollution Guidelines for Existing Power Plants and Emission Standards for Modified or Recontructed Power Plants, pp. 3-25 to 3-28, http://www2.epa.gov/sites/production/files/2014-06/documents/20140602ria-clean-power-plan.pdf

53 The 2012 and 2013 figures for natural gas consumption are from the AEO2014.

${ }^{54}$ EPA "Regulatory Impact Analysis for Carbon Pollution Regulations for Existing Power Plants", June 2014 , pp. 3-36.
} 

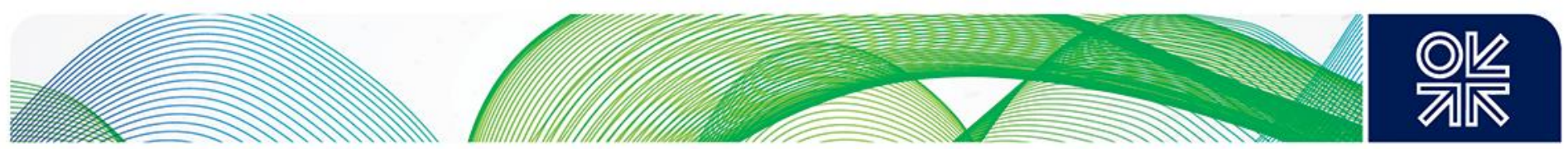

moving the country one large step in the right direction. Partly in order to achieve this outcome, the planned emission reduction will be modest.

The other interpretation, which I share, is that the process will be subject to delays and litigation and that the regulations will be open to change. One of the reasons to anticipate delay and litigation is the opposition from the parties that are expected to bear a heavier share of the compliance burden. On that interpretation, the issue is not whether the regulations go into effect but rather than how long it will take, what the costs will be, and how effective the regulations will be once court challenges have been resolved and the multiple state mechanisms have been introduced.

It is expected that litigation will occur, with states, companies and NGOs challenging the EPA. Legal precedent ${ }^{55}$ suggests that the courts will support the EPA in its efforts to regulate $\mathrm{CO} 2$ emissions, and that states will have a hard time defying the regulations. However, there are good lawyers on both sides and judges can be unpredictable, especially when it comes to the limits in the underlying legislative mandate, precedent and the standard of not being 'arbitrary or capricious'. In this case, a lot of emphasis is being placed on the validity of the CAA, which was written for conventional pollutants, and on a section of the law that has not been used before to justify the sort of rules that are being proposed.

We should also not forget that Congress has been focusing on putting limits on EPA actions and budgets. If the Republicans were to take control of the Senate in the mid-term elections, the pressure on the EPA would certainly mount, and I think it is not unreasonable to envisage a situation where a future Republican president would significantly weaken the EPA rule, or abandon the EPA process altogether.

\section{e. State politics and security of supply}

At the state level, there are two additional issues that will have a bearing on the reaction to EPA regulations that affect coal and coal-based electricity. The first is related to the security of electricity supply, which - some utilities have argued - could be undermined by closure of coal plants in specific areas of the country. The second is the potential for the coal issue to influence the outcome of state and federal elections, which in turn could influence the prospects for legislation and regulations related to climate change.

\section{Security of supply}

Due to the extremely cold weather this past winter, there has been concern over the possibility of power shortages. It has been argued that EPA regulations could trigger closure of coal-fired power stations, which in turn could reduce the reliability of electricity supplies. For instance, American Electric Power (AEP) reported that power plants slated to close in the Midwest due to EPA regulations were running at maximum output to cope with the cold weather. Had the retirements already occurred, AEP argued, the consequences could have been more severe; instead of pleas to turn down thermostats or conserve electricity, there would likely have been rolling blackouts. The Midwest 
Independent System Operator (MISO) has also said that it is concerned about reliability related to closure of coal plants ${ }^{56}$.

The EIA recently published a paper on the relationship between growing demand for gas in the power sector and the risk posed to electricity system reliability during periods of system peak (during the winter, for example) in the northeast area of the US ${ }^{57}$. The increased use of natural gas in the power sector has contributed to low utilization of non-gas plants, such as those using coal and oil, and to the expectation that these underutilized plants would close. This would not be a concern if gas-fired plant were able to meet peak demand. However, the coincidence of the gas demand peaks for heating and power has led to gas pipeline capacity constraints, which in turn has created reliability concerns for electricity power deliveries (of gas). To the extent that the EPA performance standards could trigger closure of coal plants, states and utilities will be quick to challenge the standards. The EPA argues that it has taken the security issue into account in designing its standards, but I anticipate that this will be an important issue. It certainly deserves closer study.

It is important to recall that, under the EPA guidelines, states are authorized to define the mechanisms that will apply to existing power plants, so states will have the flexibility to keep power stations open if they consider this to be necessary for reasons of security of supply.

\section{Mid-term elections}

The 'war on coal' is an important mid-term election issue in some states, notably the mining states of West Virginia and Montana, both of which have Democratic senators who are retiring. The Republicans are gleefully tagging likely Democratic candidates with what they argue is President Obama's EPA-led 'war on coal' - particularly in West Virginia where polls suggests the Republicans have a good chance of taking Senator Rockefeller's seat. The state has traditionally voted Democratic, in part because most voters are poor, blue collar and in favor of government support programs, but they also see mounting job losses because of environmental regulations, both air and water.

The relevance of the 'war on coal' will vary from one state to another and will be irrelevant in many. However, the issue arises in coal-producing states as well as in states where closure of coal plants could lead to concerns about supply security.

\section{Analysis of AEO Reference Scenario and sensitivities}

The paper has introduced and analyzed four variables that potentially influence the role of coal and natural gas in the power sector, as well as $\mathrm{CO} 2$ emissions: gas/coal price differentials, growth of renewables, slow or negative electricity demand, and regulation of $\mathrm{CO} 2$ emissions. This part of the paper uses the EIA NEMS model ${ }^{58}$ to explore quantitatively how these variables could affect the

\footnotetext{
56 https://www.misoenergy.org/Library/Repository/Communication\%20Material/OnePagers/EPA\%20Compliance MISO\%20Concerns.pdf http://www.eia.gov/naturalgas/issuesandtrends/deliverysystem/2013/ (last consulted 21 June 2014). 58 NEMS stands for National Energy Modeling System. The interactive version of this model is available here: http://www.eia.gov/oiaf/aeo/tablebrowser/. A description of the model and its assumptions for AEO 2103 is available here: http://www.eia.gov/forecasts/aeo/assumptions/pdf/0554\%282013\%29.pdf
} 

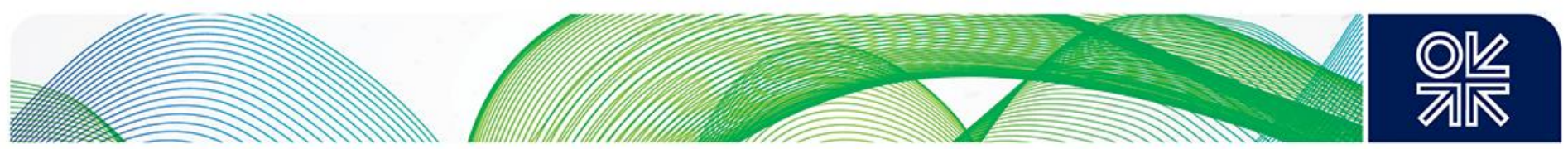

domestic consumption of coal and natural gas; $\mathrm{CO} 2$ emissions and prices in the US power sector; as well as electricity prices and trade of natural gas.

I have used the interactive tool associated with the EIA's Annual Energy Outlook (AEO) for 2014, which does not incorporate the impact of the EPA's proposed regulation of $\mathrm{CO} 2$ emissions. That tool is useful to study sensitivities related to the variables identified. However, it is limited in the sense that it is not possible to construct new sensitivities that are not already pre-specified. Thus, for instance, it is not possible to analyze a combination of low coal prices, high gas prices and different $\mathrm{CO} 2$ prices. Nor does it allow for negative growth in electricity demand, which is part of the main EPA scenario. Consequently, I am not able to analyze quantitatively relevant sensitivities, though I nevertheless qualify the AEO sensitivities where necessary.

The first of four subsections briefly summarizes the results of the AEO2014 Reference Scenario to 2040. The next examines the impact of the four sensitivities on coal and gas consumption in the power sector. The third explores the impact of the sensitivities on $\mathrm{CO} 2$ emissions from the power sector, while the fourth considers the impact of the sensitivities on electricity prices and natural gas exports.

\section{a. Reference scenario}

According to the AEO 2014 Reference Scenario, electricity generation rises at 0.9 per cent per annum, with a total of 5,219 billion $\mathrm{kWh}$ in 2040. Coal's share of the power market falls from 37 per cent in 2012 to 32 per cent in 2040, natural gas's share rises from 30 per cent to 35 per cent, and the renewable share rises from 12 per cent to about 16 per cent. $\mathrm{CO} 2$ emissions from the power sector rise at 0.2 per cent per annum, from 2,039 million tonnes of CO2 in 2011 to 2,271 million tonnes in 2040. Electricity prices in real terms rise by 0.4 per cent per annum, and the US moves from being a net importer of natural gas ( $1.5 \mathrm{Tcf})$ to being a net exporter (5.7 Tcf).

\section{b. Domestic coal and gas consumption}

I look first at the impact of the four sensitivities (low cost of coal, low cost of renewables, low demand, carbon fee) on the market shares for coal and natural gas in the power sector, and then at the forecast consumption of each fuel.

\section{Cost of coal}

The EIA has modeled a range of sensitivities on the relative costs of coal and natural gas for the power sector 59 . The Reference Scenario assumes that natural gas prices will rise 3.1 per cent per annum, compared to an increase of 1 per cent per annum for coal. Real coal prices rise from $\$ 2.39$ in 2012 to $\$ 3.19$ in 2040 ; real natural gas prices rise from $\$ 3.51$ to $\$ 8.34$ /thousand cubic feet over the same period. 
The 'low cost of coal' sensitivity assumes that mine productivity is about 2.5 per cent per year higher than in the Reference Scenario, and that mining wages, mining equipment and coal transportation rates are about 25 per cent lower in 2040 compared to the Reference Scenario. In this sensitivity, coal's share rises above 34 per cent (from 32 per cent) and the share of natural gas falls slightly to 34 per cent (from 35 per cent), although total generation rises. In the 'high coal cost scenario', which assumes that annual mine productivity is 2.5 per cent lower and other costs are 24-31 per cent higher than in the Reference Scenario, coal's share falls to 26 per cent and natural gas's share rises to 39 per cent, although total generation also falls.

As argued earlier in the paper, I think the EIA assumptions on coal and gas prices are questionable, because they assume that US gas prices are effectively decoupled from oil prices and that coal prices remain relatively high. As in Europe, a larger differential between the prices of natural gas and coal could increase the market share of coal, even in the presence of a carbon price.

\section{Lower cost of renewables}

This sensitivity assumes, inter alia, a 20 per cent reduction in the capital costs of new non-hydro renewable power until 2040. Coal's share is slightly below the Reference Scenario (32 per cent), natural gas's share is 31 per cent (compared to 35 per cent in the Reference Scenario) and Renewable Power's share is 21 per cent (compared to 16 per cent in the Reference Scenario) ${ }^{60}$. It is interesting to note that the increase in renewables has a larger negative impact on natural gas than on coal.

\section{Low demand}

This scenario assumes a 0.2 per cent per annum increase in electricity demand throughout the period, compared to a 0.9 per cent increase in the Reference Case. This reflects, inter alia, the adoption of the best available (most efficient) technologies on the demand side. Compared to the Reference Scenario, this reduces the share of coal to 31 per cent and the share of natural gas to about 32 per cent, but more importantly it reduces the volume of natural gas used in the power sector by about 25 per cent and for coal by about 20 per cent.

This sensitivity does not reflect the impact of a decline in demand, as forecast by the EPA in its impact analysis of the proposed performance standard for existing power stations. In the EPA forecast, a reduction in electricity demand of 11 per cent in 2030 (compared to the business as usual forecast) reduces both coal and gas-based generation.

\section{Carbon fee}

The Reference Scenario does not include a carbon fee, nor does it assume that the EPA's emission standards are implemented. However, it does reflect the possibility of such regulation by including a 3 per cent increase in the cost of capital when evaluating new coal-fired power plants without CCS. The model has different carbon prices sensitivities, ranging from $\$ 10$ to $\$ 25 / \mathrm{tCO} 2$, and in each case the carbon price is introduced in 2015 and then escalates annually at 5 per cent. The carbon price has an important impact on the relative shares of the two fuels. For instance, with a $\$ 10 / \mathrm{tCO} 2$ carbon price, coal's share of the market falls to 19 per cent by 2040, while natural gas retains about 34 per cent of the market. In this sensitivity, the main beneficiaries are renewable energy and nuclear, but if natural 
gas prices are assumed to rise more slowly than in the Reference Case (2.7 per cent rather than 3.1 per cent), then natural gas could increase its market share substantially. The impact on coal is even more striking with a $\$ 25 / \mathrm{tCO} 2$ price; coal-based generation is virtually wiped out.

As explained before, this sensitivity assumes the EIA Reference prices for coal and natural gas. With a higher price differential favoring coal over natural gas, the negative impact on coal would be less.

The graphics ${ }^{61}$ and analysis below summarize the implications of the key sensitivities for the forecast consumption of natural gas and coal in the US power sector until 2040.

\section{Coal consumption (Graphic 10)}

For the sensitivities involving lower coal costs and lower-cost renewables, coal consumption rises throughout the period and is within the range of 900 million short tons (Mt) to 1,000 Mt in 2040, compared to the Reference Case of $909 \mathrm{Mt}$ for 2040, and above the 2012 figure of $825 \mathrm{Mt}$. However, in the low-demand sensitivity, coal consumption in the power sector in 2040 falls to $727 \mathrm{Mt}$, while in the $\$ 10 /$ t carbon price sensitivity (GHG10), coal consumption in the power sector is only $510 \mathrm{Mt}$ in 2040. In the $\$ 25 / \mathrm{t}$ carbon price sensitivity (not shown here), there would be virtually no coal consumed in the power sector. This is the only EIA scenario that is consistent with the IEA '450 Scenario', in which CO2 emissions from coal-based generation are below 100 million tonnes.

\section{Graphic 10: Coal consumption in the US power sector, 2010-2040 (million short tons)}

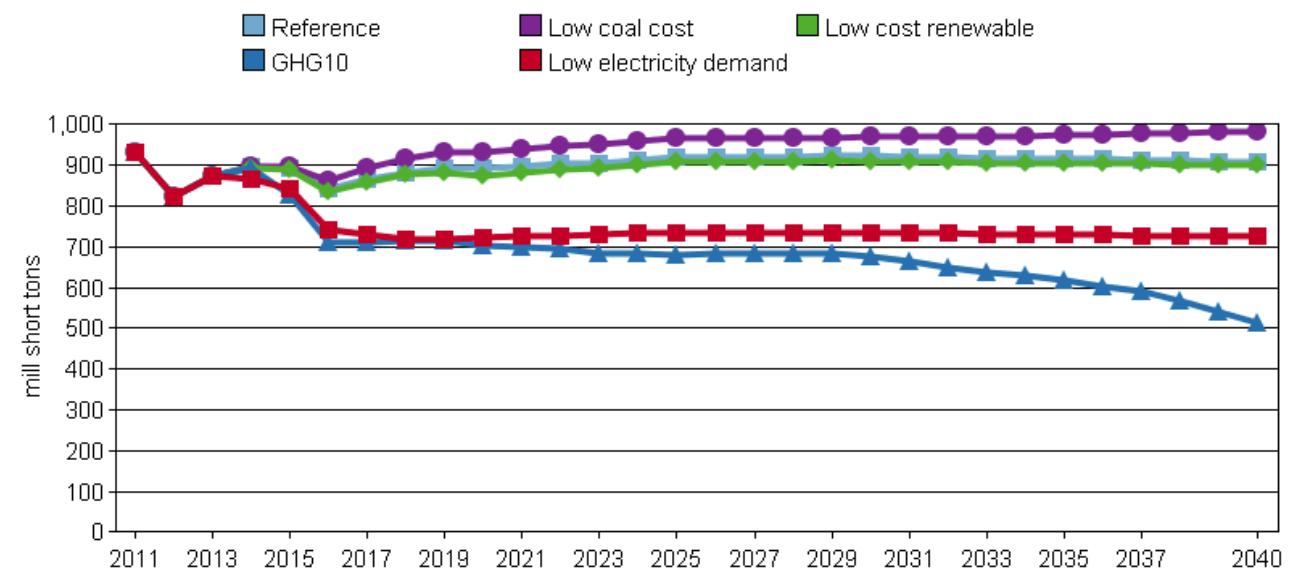

\section{Natural gas consumption (Graphic 11)}

First, under the low demand sensitivity, natural gas consumption falls from 9.25 Tcf in 2012 to 8.4 Tcf in 2040. Second, lower costs of coal and especially lower costs of renewables reduce natural gas consumption compared to the Reference Case. Third, although the immediate impact of a $\$ 10$ carbon price would be to increase the demand for natural gas to $11 \mathrm{Tcf}$, at the expense of coal, consumption of natural gas would eventually decline as the carbon price rose, with natural gas and coal being replaced by greater output from both renewables and nuclear power. Although I have not included them here, other sensitivities would result in much higher natural gas consumption. For instance if the 

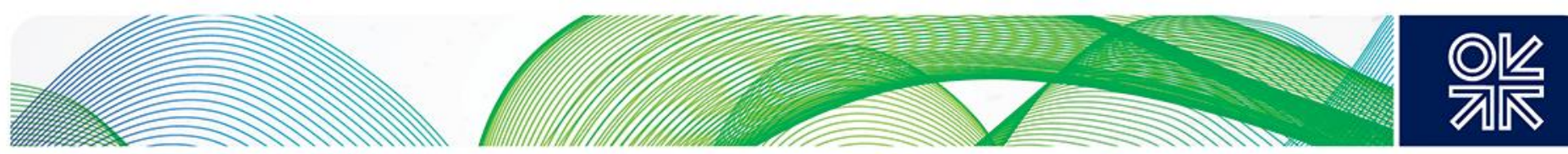

price of natural gas were much lower than in the Reference Scenario, the share of natural gas would rise at the expense of both coal and nuclear.

\section{Graphic 11: Natural gas consumption in the US power sector (Tcf), 2010-2040}

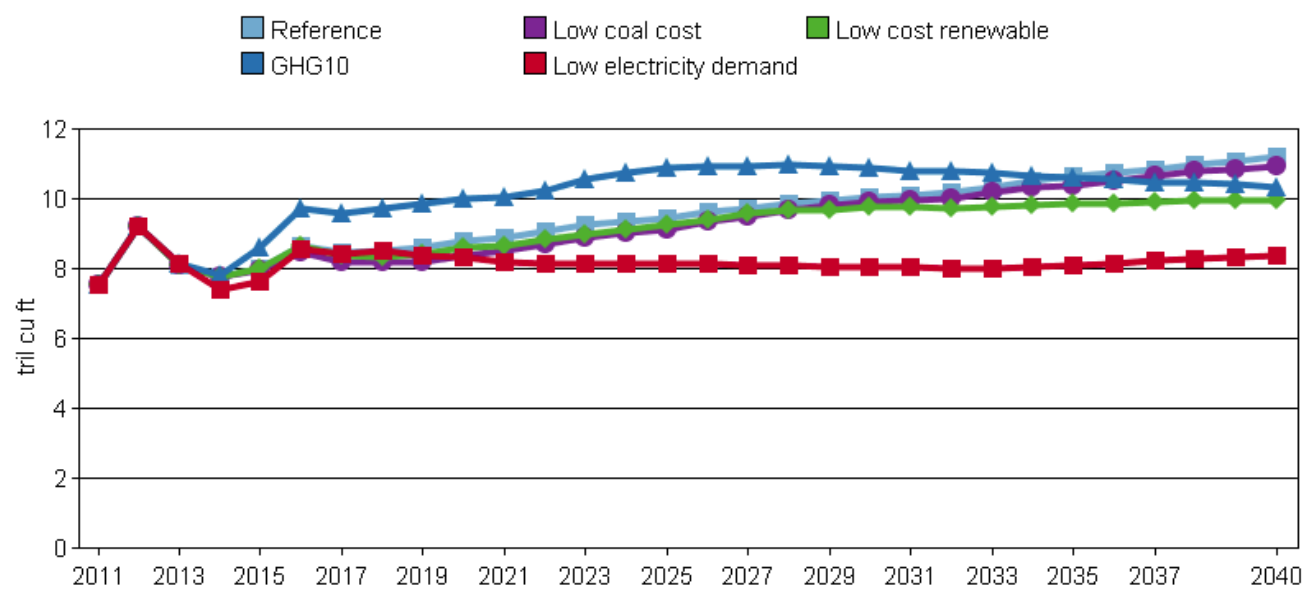

\section{c. CO2 emissions from the US power sector}

The consequences for $\mathrm{CO} 2$ emissions for the whole electricity sector (not just coal) are summarized in Graphic 12. Under the Reference Scenario, and in the sensitivities with lower coal costs and lower renewables costs, total CO2 emissions from the power sector are higher in 2040 than they were in 2012 (2039 million tonnes - about 38.5\% of US energy-related CO2 emissions). On the other hand, in the low-demand scenario, CO2 emissions fall to about 1771 million tonnes, while in the $\$ 10 / t$ carbon fee sensitivity, CO2 emissions fall to 1446 million tons by 2040. In the Reference Scenario and most of the sensitivities, coal is easily the largest emitter of CO2 emissions. However, in the $\$ 10 / t$ carbon fee sensitivity, both coal and natural gas are important emitters. The only sensitivity where CO2 from coal-based generation is negligible (and consistent with the IEA '450 Scenario') is with a \$25/t carbon fee; in that case, $\mathrm{CO} 2$ emissions in the power sector come essentially from natural gas. However, as explained before, these conclusions on $\mathrm{CO} 2$ emissions need to be qualified since they assume the AEO2014 Reference prices for coal and natural gas. 


\section{Graphic 12: Energy related CO2 emissions from the US power sector}

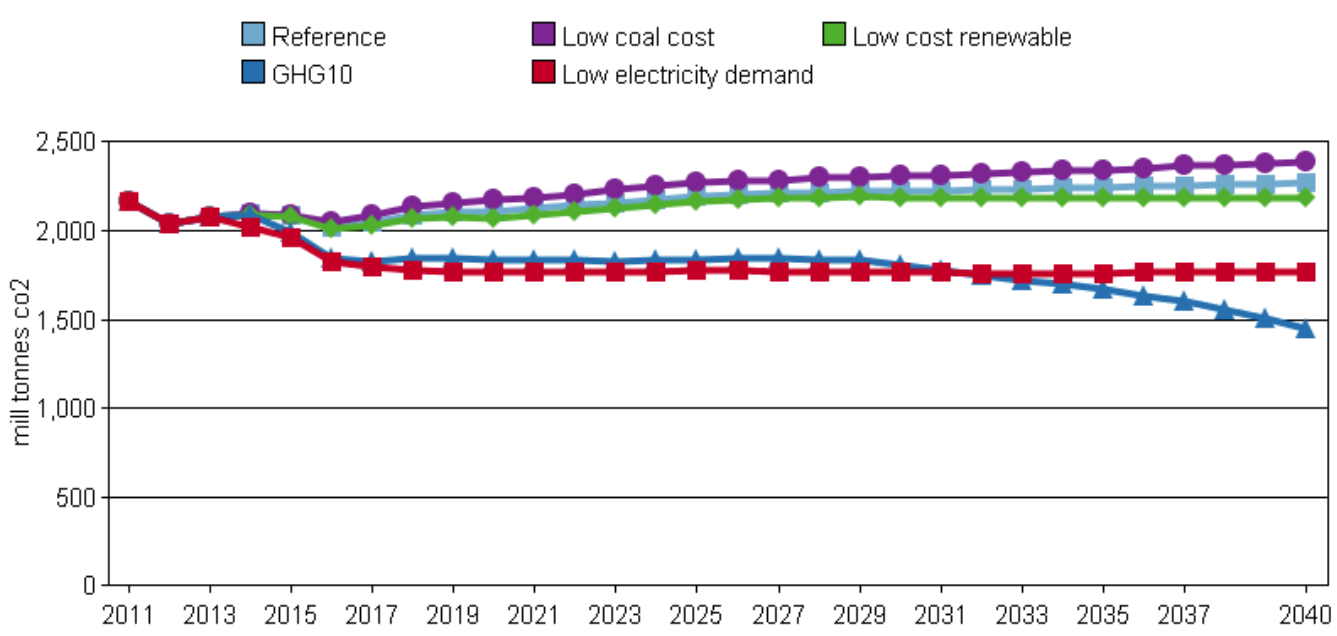

\section{d. Electricity prices and natural gas trade}

Graphic 13 includes EIA forecasts for the real price of electricity in the US in $2012 \$$ under the Reference Scenario and the four sensitivities. In the AEO2014 Reference Scenario, real electricity prices rise by 0.4 per cent per annum; this is approximately the same rate as in the sensitivities involving lower coal costs and lower renewable costs. However, in the low-demand scenario, electricity prices are essentially flat, while in the $\$ 10 / t$ carbon price scenario, electricity prices rise at double the rate in the AEO2014 Reference Scenario.

\section{Graphic 13: Electricity price in the US}

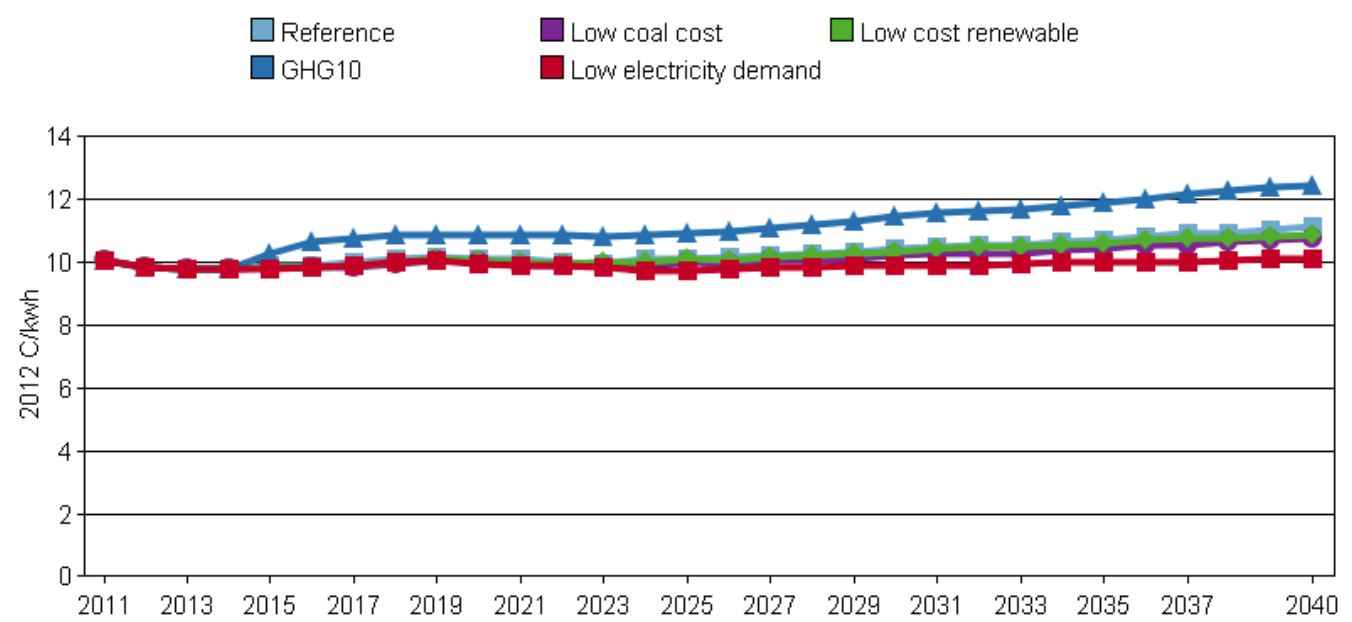

With respect to trade in natural gas (Graphic 14), the Reference Scenario sees US net imports falling from about $1.5 \mathrm{Tcf}$ in 2012, becoming net exports of about 5.8 Tcf by 2040. The US continues to be a 
net importer from Canada (about $0.7 \mathrm{Tcf}$ ). Net exports are divided between pipeline exports to Mexico (3.1 Tcf) and LNG exports (3.4 Tcf). Under the low electricity demand sensitivity, natural gas exports are higher than in the Reference Scenario, whereas the opposite is true for the carbon fee sensitivity.

The logic appears to be that a lower demand for electricity implies lower domestic demand and prices for natural gas, raising the potential for exports; and that the carbon fee raises domestic demand and prices for natural gas, thereby reducing the potential for exports.

\section{Graphic 14: Net imports of natural gas for the US}

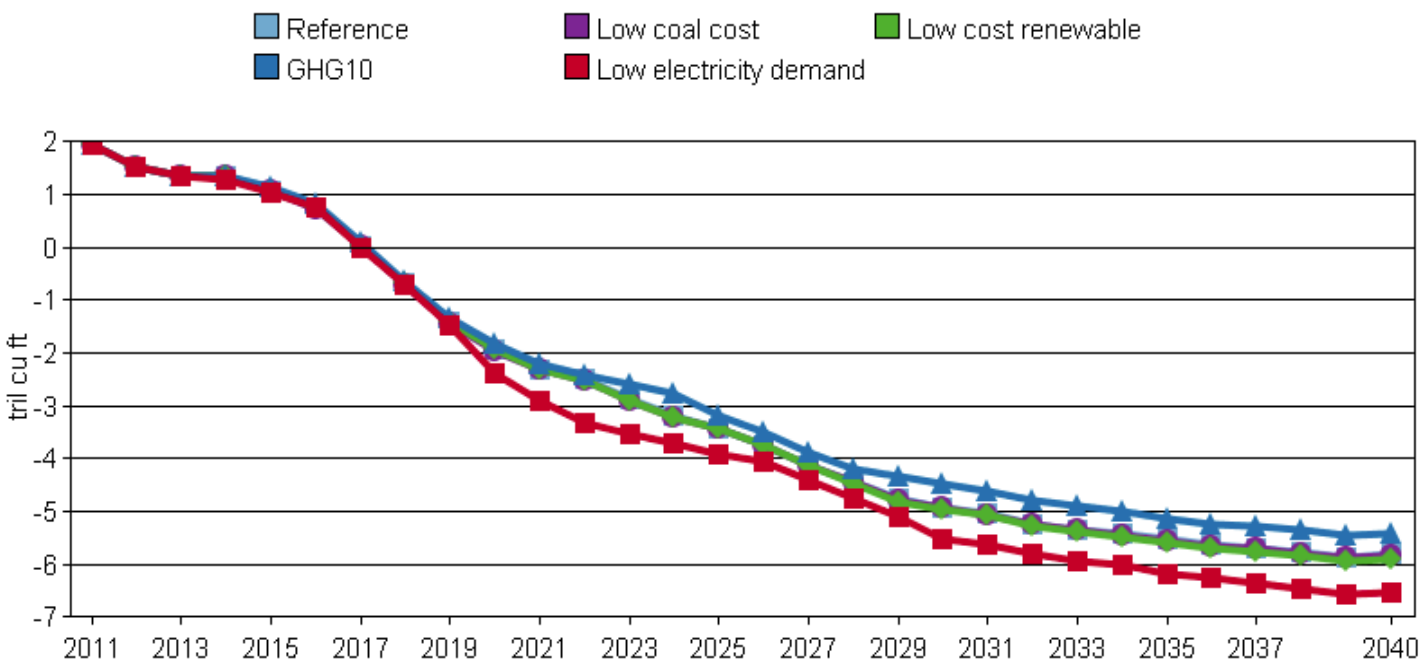

\section{Conclusions}

First, reductions in $\mathrm{CO} 2$ emissions from the US power sector are likely to be modest, at least from a European perspective. If successfully introduced, the EPA's proposed performance standards for existing power stations imply a reduction in US power sector emissions of 18 per cent in 2030, compared to 2012. Under the proposal, the EPA expects coal and gas each to generate at least 30 per cent of US electricity, so the US will rely on these two fuels for at least $60 \%$ of its generation.

Second, achieving EPA objectives for $\mathrm{CO} 2$ emissions reduction will be difficult, which partly explains why the targets are modest. There is no bipartisan consensus on the need to address climate change in the US. Furthermore, there will be strong opposition from states whose compliance costs are high and from the directly affected producers and consumers of coal and coal-base electricity. Litigation and delay is likely. A change in the Senate majority or in the party holding power after the next presidential election could slow the process further or even lead to the abandonment of the approach taken by the current administration.

Third, the prospects for coal and natural gas in the power sector depend not only on EPA regulations, but also on electricity demand, the growth of renewables and the relative cost of natural gas and coal. 
While the market share for natural gas will grow, its market in the power sector will be limited by rising natural gas prices, growth of renewables and flat or declining electricity demand.

Finally, the US has taken an important first step to regulate CO2 emissions at a federal level, and this will give the US something to show in the preparations for reaching a global climate change agreement in Paris in 2015. This may encourage other countries to take action too. However, the absence of bipartisan consensus weakens US credibility and global leadership. A central challenge for the US is to build bipartisan political support, as well as wider public support for federal action to tackle climate change. 